\title{
El Derecho particular de la Iglesia según el Código de 1983
}

\section{INTRODUCCIÓN}

Se entiende aquí por Derecho particular a la legislación episcopal o especial, que afecta a cada Iglesia particular o diócesis a tenor de los cc. 12-13 ${ }^{1}$. No se pretende entrar en posibles precisiones terminológicas, ni conceptuales, aunque en parte fue objeto de una ponencia al comenzar las VI Jornadas Informativas de la Asociación Española de Canonistas, celebradas en Madrid del 11 al 13 de abril de 1983.

El título «Derecho particular de la Iglesia en España» no comprende a todo lo tratado en las VI Jornadas Informativas, por lo que se ponía, como subtítulo, «Experiencias de la aplicación del nuevo Código» con la aclaratoria de que se iba a informar «sobre el Derecho particular de la Conferencia Episcopal Española y de las diócesis españolas» ${ }^{2}$.

Dentro del Derecho particular se puede comprender también al Derecho parroquial y al de los Institutos de vida consagrada y Sociedades de vida apostólica. Así como el Derecho común o universal puede ser general (para todos los fieles) y singular (para una clase de fieles) así hay también un Derecho particular general con normas comunes a todos los Institutos de vida consagrada (cc. 573-606) y otro singular o especial para los Institutos religiosos (cc. 607709), para los Institutos seculares (cc. 710-730) y para las Sociedades de vida apostólica (cc. 731-746). En las VI Jornadas Informativas no se dedicó una ponencia a los Institutos de vida consagrada, como en la XIX Semana Espa-

1. A. Prieto, «Cuestiones fundamentales» en Nuevo Derecho Canónico. Manual universitario (Madrid, BAC, 1984) 84; J.M. ${ }^{a}$ PINEERo, Nuevo Derecho Canónico (Madrid, Atenas, 1983) 30-31.

2. Programa de las VI Jornadas Informativas de la Asociación Española de Canonistas en Madrid del 11 al 13 de abril de 1985 p. 4. 
ñola de Derecho Canónico sobre el «Derecho patrimonial», porque en esta materia, gran parte del Derecho particular de la Conferencia Episcopal y de los Obispos obliga también a los religiosos, especialmente en el aspecto litúrgico y pastoral, dejando a salvo su exención, como luego veremos.

Se está escribiendo tanto sobre el Código de 1983 en estos dos últimos años que resultaba superfluo insistir sobre el tema genérico del mismo o de uno de sus libros. Era mejor ver cómo evolucionaba el Derecho particular, al que el Código de 1983 deja un amplio margen discrecional, dentro de los postulados de subsidiaridad y flexibilidad, respetando las orientaciones y principios establecidos en el Concilio Vaticano II y legislación posconciliar, según observó D. Luis Martínez Sistach, Presidente de la Asociación de Canonistas, al comienzo de las VI Jornadas Informativas.

Por tratarse de un auditorio de especialistas o de personas bastante capacitadas en Derecho Canónico, se daba por supuesto el conocimiento de algunas cuestiones previas, que es necesario aclarar para el lector corriente $u$ ordinario.

\section{a) El problema de la centralización y descentralización en la Iglesia}

Conexo con el tema del Derecho particular está el tema del primado jurisdiccional del Romano Pontífice con una centralización de la legislación general y el de la descentralización mediante la legislación episcopal o propia de los Institutos religiosos.

Ya en las primeras colecciones del primer milenio, aparece una oscilación centralizadora con los concilios generales y descentralizadora con los concilios particulares, aunque algunas decisiones de estos últimos, al ser confirmadas por otros también particulares, llegaron a generalizarse e incorporarse a la legislación oficial o universal de la Iglesia. Esto sucedió, por ejemplo, con algunas decisiones del Concilio de Elvira (306) sobre el celibato y otras de los concilios africanos del tiempo de San Agustín ${ }^{3}$.

Son claramente centralizadoras las colecciones canónicas del Papa Gregorio VII o elaboradas bajo la influencia de la reforma gregoriana, mientras que son descentralizadoras el Decreto de Burcardo de Worms y el Decreto de Ivo de Chartres. Algunas colecciones particulares, como la Trullana (691) junto con otras motivaciones bastante complejas, llegaron a fomentar el distanciamiento respecto a la Sede de Roma, hasta consumarse la escisión definitiva con Miguel Cerulario (1054) ${ }^{4}$.

3. A. GARCla, Historia del Derecho Canónico. El Primer Milenio (Salamanca, IHTE, 1967) 164-166.

4. Ibid., pp. $277-278$ y 349-350. 
La centralización y la descentralización son dos movimientos necesarios, que se contrastan mutuamente, como la inspiración y espiración de los pulmones y como la sístole y diástole del corazón. Se dio un movimiento descentralizador en Alemania e Inglaterra, al que siguió lógicamente otro centralizador durante la Edad Media, viniendo luego la reacción conciliarista. Ambos deben armonizarse para evitar riesgos. «La arritmia o el desconcierto que pudieran originarse por insistir más en un sentido (excesivo) o en otro, por querer empujar más hacia dentro o hacia fuera, lo mismo da - como dice D. Juan Sánchez- o por hacerlo a destiempo, producirían trastornos inevitables, siempre serios, en el organismo eclesial» ${ }^{5}$.

El movimiento centralizador tiene su línea más ascendente en los Concilios Lateranense IV (1215), Trento y Vaticano I, a los que siguen el Código de 1917 y el papa Pío XII, iniciándose un movimiento descentralizador con el papa Juan XXIII y el Concilio Vaticano II. Ya antes, con el desarrollo de la doctrina sobre el Colegio Episcopal y la Iglesia local, se establecieron las bases para una mayor descentralización. Contribuyeron no poco a esto las Conferencias Episcopales, cuyo origen suele ponerse en Alemania, bajo el Pontificado de Pío IX, extendiéndose luego por Europa y el resto del orbe católico, hasta el punto de que ya en 1960 había más de cuarenta Conferencias Episcopales ${ }^{6}$.

El movimiento descentralizador se confirma con la reforma de la Curia Romana mediante la Constitución apostólica Regimini Ecclesiae universae (1967) y complementada por el papa Juan Pablo II. Con el Código de 1983 se abre un amplio espacio autonómico para el Derecho particular y una mayor corresponsabilidad por parte de los obispos y demás ordinarios.

\section{b) La exención de los Institutos de vida consagrada}

Otro tema conexo con el Derecho particular es el de la exención de los religiosos, que presenta algunas dificultades a los obispos diocesanos, como lo reconoció Mons. Rouco Varela en su intervención, dada la autonomía que se les reconoce en el Código de 1983 por utilidad común (c. 591). Precisamente, la exención es una pieza clave para salvaguardar el Derecho propio o particular de los Institutos de vida consagrada. A manera de coordenadas puede solucionar muchos problemas difíciles.

$\mathrm{E}$ l problema de la exención se remonta al siglo $\mathrm{V}$ con un sometimiento a los obispos diocesanos según el Concilio de Calcedonia (451) o directamente al

5. J. SÁNCHEZ, «Centralización y descentralización. Curia Romana y Conferencias Episcopales» en Dinámica Jurídica Postconciliar (Salamanca, Universidad Pontificia, 1969) 155.

6. Ibid., p. 188. 
papa como la abadía de Bobbio (628) o al rey, como la abadía de Rabais en la Champagne, al rey Dagoberto (629). La exención se extiende y propaga con la reforma cluniacense y gregoriana. Esta problemática se acentuó y solucionó en el siglo XIII con las Órdenes mendicantes, que logran la exención, como algo necesario con potestad de jurisdicción para su apostolado supradiocesano. La exención, según Egidio Romano, debía tener sus límites en contra de la opinión de Santiago de Therines, defensor de la exención total ?.

La exención, que aparecía en el Código de 1917 (cc. 615-619) entre los privilegios de los religiosos, desaparece como tal, aunque no todos los privilegios hayan desaparecido, pues se sigue hablando de ellos en los cc. 76-84 y hay que respetar los derechos adquiridos. En el Concilio Vaticano II se precisó mejor la naturaleza de la exención, que como recoge el Código de 1983 se justifica: «Para promover mejor al bien del Instituto y a las necesidades del apostolado» (c. 951) ${ }^{8}$.

Si cada uno de los miembros de los Institutos de vida consagrada está obligado a obedecer al Sumo Pontífice, como Superior supremo, también en virtud del vínculo de obediencia (c. 590 § 2), lo está igualmente al obispo diocesano en algunas materias, como veremos posteriormente, máxime si pertenece a un Instituto de Derecho diocesano (c. 589). En todo caso se reconoce a cada uno de los Institutos una justa autonomía de vida, sobre todo en el gobierno (c. $686 \S 1$ ) para conservar íntegro el patrimonio peculiar, según su naturaleza fundacional, como lo establece el c. 578. «Corresponde a los Ordinarios del lugar el conservar y defender esta autonomía» (c. $586 \S 2$ ).

Hay bastantes cánones que hacen referencia a la Santa Sede, mientras que otros se refieren a la vinculación con los obispos diocesanos u Ordinarios del lugar, cuya enumeración omitimos 9 . Basta citar como botón de muestra el c. 683 sobre el derecho del obispo a visitar iglesias, etc.

La autonomía de los Institutos de vida consagrada se ejercita y protege a través de las Conferencias de Superiores mayores (cc. 708-709) que, al unir sus esfuerzos para el logro de sus objetivos, deben dejar a salvo la índole y espíritu de cada instituto con su Derecho propio y sus espacios autonómicos. En España fue erigida la Conferencia de religiosos el 21 de mayo de 1954, con inclusión de los Superiores y Superioras Mayores hasta febrero de 1969, en que se procede a la separación de las Superioras Mayores. Desde 1962 ha venido fun-

7. I. Rodríguez, Egidio Romano y el problema de la exención religiosa (Madrid 1958) 24-28 y 77-90.

8. Se tiene en cuenta a la Lumen gentium, n. 45 y Christus Dominus, n. 35.

9. D. J. ANDrés, El Derecho de los religiosos (Madrid 1983) 16-24. 
cionando la Revista Confer, «como un medio de expansión y comunicación de espíritu, y de impulso orientador» ${ }^{10}$.

Dentro de la CONFER (Confederación Española de Religiosos) han funcionado distintos organismos directivos, a los que se han añadido otros, como la Federación Española de Religiosos Educadores (FERE) y una Comisión mixta para la oportuna coordinación entre obispos y Superiores Mayores ${ }^{11}$.

En toda esta materia hay que tener en cuenta, además del Código de 1983, las orientaciones del Concilio Vaticano II y otros documentos, como Mutuae relationes, Notas directivas para obispos y religiosos del 14 de mayo de 1978 , dentro de una pastoral de conjunto ${ }^{12}$.

En algunas Constituciones de Institutos de vida consagrada se habían establecido normas o disposiciones, que son contrarias al Código de 1983, por lo que deben corregirse, como lo referente a la sustitución de los votos simples en los Institutos religiosos por otros vínculos a tenor del c. $653 \S 2$. Quienes los hayan hecho deben emitir votos al cumplirse el tiempo de los mismos de acuerdo con los cc. 655 y $658,2{ }^{\circ}{ }^{13}$.

\section{c) La diócesis y la parroquia como Iglesia particular y comunidad}

Los conceptos de diócesis y de parroquia, que actualmente están bien definidos y precisados con caracteres distintos, tuvieron cierta confusión en sus orígenes, con nombres fluctuantes, llamándose unas veces diócesis y otras parroquia a la circunscripción territorial del obispo.

La palabra parroquia viene del griego (paroikía o paroikein) que significa cohabitar y administrar, mientras que para los cristianos significaba vivir en el extranjero, como peregrinos en este mundo, según testimonio de San Pedro ${ }^{14}$.

$\mathrm{Al}$ extenderse la Iglesia por las ciudades y campiñas, fueron surgiendo los corepíscopos en Oriente y los párrocos en Occidente para atender a las iglesias rurales, aunque también en Occidente hay corepíscopos de modo raro en los

10. Ibid., p. 659; A. FernándeZ, «Presentación» de là Revista Confer, 1 (1962) 7-8.

11. A. Bocos, «Religiosos educadores. Ser y quehacer de la FERE», Vida Religiosa, 50 (1981) 344-367.

12. D.J. ANDREs, «Obispos y religiosos en la Iglesia, comentarios al documento Mutuae relationes», Revista Española de Derecho Canónico, 34 (1979) 525-657. Cf. «El Vicario Episcopal para los Institutos de vida consagrada. Notas orientativas de la Comisión Mixta de Obispos y Superiores Mayores, etc.». Boletín de la Conferencia Ep. Esp. 6 (1985) 93-108.

13. S. Congregatio pro Religiosis e Institutis saecularibus; «Dantur normae pro Institutis religiosis de votis nuncupatis», AAS, 76 (1984) 500.

14. 1 Pet. 2, 11. Cf. C. Floristán, La comunidad eucarística (Madrid, BAC 1961); A. MAZZoleni, La parrocchia (Nápoles 1969); L. Bouyer, La Iglesia de Dios (Madrid, Studium, 1973) $495-496$. 
siglos V-VI y de un modo permanente en el siglo vIII, como coadjutores de los obispos ${ }^{15}$

Ya se habla de parroquias en el siglo III por el papa Dionisio (260-268) en una carta al obispo Severo, que recoge Graciano en su Decreto ${ }^{16}$. En tiempo de San Agustín, no hay todavía una nomenclatura definida, resultando el término parroquia equivalente al de diócesis, como sucede al hablarnos de la población de Fusala (castellum) en territorio hiponense, que pertenecía a la parroquia de la Iglesia de Hipona (ad paroeciam Hipponensis pertinebat) para donde presentó al adolescente Antonio. Este joven presbítero fue consagrado obispo de Fusala con funestas consecuencias ${ }^{17}$.

Se habla también de la paroecia Ecclesiae Calamensis, donde estaba el presbítero Restituto ${ }^{18} \mathrm{y}$ de la iglesia de Thiave, que equivale a una parroquia actual, atendida por el presbítero Honorato ${ }^{19}$. Aparecen villas y núcleos rurales (castella) donde a veces había obispo y otras presbítero (párroco); pero lo que más nos interesa en su doctrina es el que «todos somos miembros de una misma familia o grey», donde somos también «condiscípulos» ${ }^{20}$. Varios monjes agustinos llegaron a ser obispos.

Debemos estar, según San Agustín, dispuestos a servir a la Iglesia. Si ella os pide algún trabajo, «no lo recibáis con avidez, ni lo rechacéis por indolente desidia... No antepongáis vuestro ocio a las necesidades de la Iglesia, pues si no hubiese buenos ministros que se determinasen a asistirla, cuando ella da a luz, no hubiésemos encontrado medio de renacer» ${ }^{21}$. Tanto para el modo de catequizar, como la preparación de los catequistas, aparece en las obras $D e$ catechizandis rudibus y en De Doctrina christiana, utilizadas por los doctrineros y misioneros agustinos en la evangelización de las Indias orientales y occidentales ${ }^{22}$.

Hay estudios especiales sobre las parroquias rurales y arciprestazgos desde el siglo v hasta el IX en las Galias (Francia) lo mismo que sobre las basílicas

15. P. IMBART DE LA TOUR, Les paroisses rurales dans l'ancienne France du IV-XIe siecle (Paris 1900); A. GARciA, o.c., pp. 299 y 386-390.

16. C. 13 , q. 1 , c. 1 .

17. S. Agustín, Epistola 209, 2 (PL 33, 933). Cf. I. OpELT, «Augustinus Epistula 20 (Divjak). Ein zeugnis für lebendiges Punisch und 5 Jahrhundert nach Christus», Miscellanea di Studi Agostiniani in onore di P. Agostino Trape (Roma, Augustinianum, 1985) 121-132.

18. De civitate Dei, 14, 242 (PL 41;433). En Calama estaba de obispo S. Posidio, primer biógrafo de S. Agustín.

19. Epistola 83, 1-2 (PL 33, 291-292).

20. Sermo 27, 1; 101, 4; y 270, 1 (PL 38, 178, 607 y 1237).

21. Epistola 48, 2 (PL 33, 188).

22. F. CAMPO, «La catequesis pastoral en el De catechizandis rudibus», Estudio Agustiniano, 7 (1972) 105-127. 
e iglesias rurales (parochiatas) en la España visigótica, estableciéndose un claro perfil de la parroquia en el siglo XI ${ }^{23}$.

Hubo concilios, como los de Ascheim (756) y Heuchin (772) que ponen dificultades a los monjes para la cura de almas ${ }^{24}$, aunque llega a reconocerse en el Concilio de Nimes (1096) que los monjes pueden dedicarse al ministerio con más rectitud que los presbíteros seculares ${ }^{25}$.

En el siglo XII aparece amplia documentación sobre las diócesis y las parroquias son clara distinción y peculiaridades. Se habla de parroquias personales distintas de las urbanas y rurales. Sobre su erección y desmembración existen normas en el Corpus Iuris Canonici ${ }^{26}$. El Concilio de Trento reconoce la capacidad de los religiosos para el ejercicio pastoral en las parroquias, llegándose al hecho paradójico de que después del Código de 1917 eran raras las parroquias atendidas por religiosos en España ${ }^{27}$.

En América, por ejemplo, había gran inserción de los religiosos en las diócesis, especialmente como párrocos, ya antes del Concilio Vaticano II, aumentando después, dada la escasez de sacerdotes y a la mayor exigencia de participación, que se reconoce a los religiosos y a los laicos. Sobre esta materia hay abundante bibliografía ${ }^{28}$. Actualmente se auspicia la corresponsabilidad de todos en la parroquia e Iglesia local.

La parroquia debe estar atendida por un sacerdote (c. 519) o por un equipo (c. $517 \S 1$ ) con tal de que uno de ellos sea el director de la cura pastoral, que dirija la actividad conjunta y responda ante el obispo. Ya no puede ser pároco una comunidad religiosa, como sucedía con el Código de 1917, c. 451 $\S 1$, sino que un presbítero tiene que ser «párroco moderador» de la parroquia erigida en una iglesia de un Instituto clerical o Sociedad de vida apostólica, «lo que se hará mediante acuerdo escrito entre el obispo diocesano y el superior competente» (c. $520 \S \S 1-2$ ) para lo que suele haber formularios ${ }^{29}$.

En caso de escasez de sacerdotes, se le puede confiar a un diácono o a otra persona que no tiene carácter sacerdotal, o a una comunidad laical, con

23. L. NANNI, La parrocchia studiata nei documenti lucchesi dei sec. VIII-XIII (Roma 1948); G. MARTínez Díez, El patrimonio eclesiástico en la España visigótica (Comillas, Santander, Universidad Pontificia, 1959) 51-65.

24. J.D. MANSI, Sacrorum conciliorum nova et amplissima colectio, 12 (Graz, 1960) 589 y 851.

25. Ibid., 20, col. 934-935.

26. X, 3, 5, 10 y 5, 31, 8; Clementinas 3, 4, 2 (E. FriedberG, II, 467, 837 y 1160).

27. F. BARBERENA IRAIzOZ, La parroquia diocesana regida por religiosos (Madrid, CONFER, 1984) 7, 68, y 72-76.

28. Ibid., pp. 249-449 y 571-578; D.J. ANDRÉs, El Derecho de los rel.; pp. 555-569.

29. L. Gutí́rReZ, «Parroquias encomendadas a religiosos», Rev. Confer, 16 (1977) 169-197. En las pp. 190-197 aparece un convenio-modelo. 
la condición de que se designe un sacerdote, que dotado de las potestades, propias del párroco, dirija la actividad pastoral (c. $217 \S 2$ ).

Prescindiendo de la doctrina teológica sobre la diócesis y la parroquia, cuyos conceptos se precisan en los cc. 369 y 515, conviene observar que mientras la diócesis «es una concreción de la Iglesia universal»; la parroquia no llega a tanto y se trata de una comunidad de fieles constituida de modo estable en una diócesis o Iglesia particular, según el c. 368, bajo la autoridad del obispo diocesano, que encomienda la cura pastoral a un sacerdote como pastor propio (c. $515 \S 1)^{30}$.

Tanto la diócesis, como la parroquia, pueden estar atendidas por religiosos, especialmente en zonas de misión, para lo que hay normas apropiadas como el c. 790, que recomienda establecer acuerdos con los superiores de los Institutos, con la observación de que en las circunscripciones eclesiásticas, bajo el régimen vicarial, los Ordinarios del lugar tienen sobre los religiosos misioneros la misma competencia que el obispo diocesano ${ }^{31}$.

\section{d) Nuevas instituciones diocesanas y parroquiales}

La sistematización de esta materia, aunque sea sólo en resumen, es sumamente importante para comprender lo que viene después y por su carácter estructural, ya que se trata de la constitución jerárquica de la Iglesia, como pueblo de Dios, que está polarizado por dos ideas fundamentales o claves: la Iglesia universal y la particular o diócesis con sus parroquias e instituciones.

Prescindiendo de algunas peculiaridades de la coordinación pastoral, como el moderador de la curia (c. $473 \S 2$ ) y lo referente a Vicarios Episcopales (cc. 476-478) etc., en el Código de 1983 aparecen nuevas instituciones, algunas promovidas por el Concilio Vaticano II y otras con antecedentes remotos o próximos.

1. El consejo de asuntos económicos con su ecónomo (cc. 492-494). Se trata de una importante innovación, especialmente la figura del ecónomo diocesano y su consejo, que consta al menos de tres miembros expertos en materia económica y en Derecho civil, y designados por el obispo. Éste o un delegado suyo lo preside (c. 492). Sobre los consejos económicos y la creación de

30. Se recoge la doctrina de Lumen gentium, n. 28; Christus Dominus, nn. 30-32; Ecclesiae sanctae I, 20-21 etc.

31. J. GARCía MARTín, «Relaciones entre Ordinarios del lugar e institutos religiosos en misiones según el Código de Derecho Canónico de 1983», Commentarium pro religiosis, 65 (1984) 122-166. Se ha superado el principio del Código de 1917 (c. 296 § 2) según el cual, el Ordinario del lugar podía nombrar o destinar a religiosos misioneros aun en contra del parecer del Superior religioso. Ya no se puede hacer. 
fondos comunes a nivel diocesano y parroquial presentó una ponencia José María Piñero Carrión.

2. El consejo presbiteral y el colegio de consultores (en España) fueron objeto de una ponencia por parte de Luis Martínez Sistach. También son instituciones nuevas (cc. 496-502). El colegio de consultores (c. 502) sustituye en parte una función del cabildo catedralicio, por lo que la Conferencia Episcopal puede establecer que la siga realizando o asuma sus funciones, lo que se ha negado en España. En opinión de Ramón García, autor de una ponencia sobre los cabildos catedralicios en España, esta decisión supone un rudo golpe para los cabildos con una vida lánguida en los últimos tiempos, salvo algunas excepciones.

3. Los consejos pastorales diocesanos e infradiocesanos (cc. 511-514 y 536) según el informe de Ángel Marzoa, que analizó los 20 años de su experiencia en España, funcionan a medias. No se tiene por ahora el éxito, que se esperaba; aunque quizás tenga porvenir más adelante esta institución especialmente a nivel parroquial.

El consejo pastoral no es obligatorio, como el consejo presbiteral y el consejo económico. Debe constituirse en cada diócesis según lo aconsejen las circunstancias. Funcionan 17 en España según los informes, con cuatro en proyecto, aunque de hecho existen más. Actualmente se están renovando los estatutos de acuerdo con el Código de 1983 y dando mayor participación a los religiosos y laicos.

4. Asociaciones privadas con personalidad jurídica, sin que sus bienes sean eclesiásticos. Esto fue objeto de una ponencia por Francisco Vera Urbano con el título «Asociaciones púbticas y privadas de fieles», con el reconocimiento del derecho de asociación según el Código de 1983 (cc. 114-123 y 298329) y la normativa correspondiente.

En las mismas Jornadas Informativas se desarrollaron otros temas sacramentales con sus innovaciones, como la preparación jurídico-pastoral del matrimonio, por Federico R. Aznar Gil, según las exigencias humanas y cristianas. Ofreció una documentación bastante completa de las distintas diócesis sobre esta materia.

Las innovaciones del Derecho «litúrgico» diocesano posconciliar fueron el tema de la ponencia de José M. ${ }^{a}$ Díaz Moreno, S.J., que tuvo la amabilidad de facilitarme una copia, gesto digno de agradecimiento. Fue una de las mejores ponencias y le prestaremos especial atención.

Terminaron las Jornadas con una conferencia de Mons. Fernando Sebastián sobre «Situación actual de las relaciones entre la Iglesia y el Estado», dạn- 
do informaciones interesantes sobre los problemas de hoy y el porvenir del mañana para la Iglesia española ${ }^{32}$.

\section{Derecho Común y DeRecho Particular en el Nuevo Código}

Éste era el título de la primera ponencia de las VI Jornadas Informativas de la Asociación Española de Canonistas, que dieron comienzo el día 11 de abril a las 10 de la mañana en el salón de actos de los jesuitas, calle Maldonado 1, Madrid, con la presentación del ponente, Mons. Antonio Rouco Varela, por D. Luis Martínez Sistach, presidente de la Asociación. El Sr. Nuncio presidió la sesión inaugural.

Mons. Rouco Varela, arzobispo de Santiago de Compostela y miembro de la Asociación de Canonistas, que ha publicado trabajos sobre esta materia con otra titulación, entregó un esquema-guión, bastante completo, por lo que nos limitaremos a transcribirlo con algún ligero comentario y observación ${ }^{33}$.

\section{A) Las razones prácticas, «el sitio en la vida» de la cuestión}

En realidad, la expresión «el sitio en la vida» es poco correcta o elegante desde el punto de vista estilístico, como lo reconoció el mismo ponente; pero al mismo tiempo muy indicativa del puesto que ocupa el Derecho en la vida. Ha aumentado la conciencia eclesial y desde los comienzos del Concilio Vaticano II se procuró conciliar lo universal con lo particular. Ahora se trata de lo siguiente:

1. Aplicar las nuevas posibilidades legislativas, que ofrece el nuevo ordenamiento canónico de la Iglesia en la perspectiva de la realización de su misión pastoral.

2. Se presupone que ha habido cambios profundos -en comparación con el Código de Derecho Canónico de 1917- en base a una renovada formulación de la Teología en la relación Iglesia universal-Iglesia particular.

3. Se trata de abordar el tema en forma introductora para encuadrar teológicamente, en justa perspectiva histórica, el estudio del Derecho particular producido ya por la Iglesia en España, especialmente por la Conferencia Episcopal Española.

32. Las crónicas sobre las VI Jornadas Informativas han sido escasas. El Presidente de la Asociación de Canonistas, Luis Martínez Sistach envió una comunicación valorativa a los miembros el 29 de abril de 1985 .

33. A. Rouco VARela, «Iglesia Universal-Iglesia Particular», Jus Canonicum, 22 (1982) 221-239. Puede servir de complemento aclarativo. 


\section{B) Planteamiento del estado de la cuestión (Status quaestionis)}

Ya en la Edad Media y después se planteó el problema de la Iglesia universal frente a la particular, la centralización y descentralización, como consta en algunas decretales. La cuestión se plántea así:

1. Delimitación teológico-histórica y pastoral-jurídica:

a) Se presupone una correcta concepción eclesiológica del binomio «Iglesia universal-Iglesia particular» sin desviaciones neo-galicanas o congregacionistas.

b) Se da por conocida la clave de comprensión católica de la Historia del Derecho Canónico en su doble y orgánica incardinación en la realidad de la Iglesia, universal y particular a la vez. Hay simultaneidad cronológica y vital de esa doble dimensión del ordenamiento canónico con pluralidad y variedad de sus expresiones históricas dentro de la órbita del Derecho latino.

c) El planteamiento del problema incluye, además del aspecto jurídico y constitucional, cómo se ordenan canónicamente las conexiones estructurales de la relación Iglesia universal-Iglesia particular y su aspecto canónicopastoral, a saber: la pregunta por los criterios canónicos y pastorales que se desprenden del actual ordenamiento del Código de 1983 para la producción y desarrollo del Derecho particular canónico.

d) Se trata, por supuesto, de avistar el problema desde la perspectiva de la creación normativa del Derecho y, preferentemente por vía o en forma legislativa.

El Derecho particular sería propiamente el de la diócesis, a la que se asimilan, como Iglesias también particulares, la prelatura territorial (no personal), la abadía territorial, el vicariato apostólico y la prefectura apostólica, así como la administración apostólica erigida de modo estable según el c. 368 . La territorialidad y la personalidad son determinantes, como principios, de la estructuración interna de la diócesis y de sus figuras analógicas, y de su aplicabilidad a las unidades pastorales menores, especialmente la parroquia ${ }^{34}$.

\section{El método o «modus procedendi» en su estudio}

Sobre esta materia Mons. Rouco, como lo hacía cuando era profesor en la Universidad de Salamanca, sigue insistiendo en el método teológico, como si se tratase de una Teología del Derecho. Por eso dice que el método es el propio de la Teología de o sobre los fundamentos del Derecho canónico. Pero hay también una fundamentación filosófica y jurídica, por lo que habrá que tener en cuenta el método jurídico con sus modalidades como es la canónica y sus implicaciones teológicas.

34. Ibid., pp. 222-223. 
Esto se estructura, según Mons. Rouco, en la praxis como sigue:

- se parte del ordenamiento positivo vigente,

- se seleccionan y sistematizan sus datos explícitos e implícitos;

- se caracterizan teológica y canónicamente;

- se proponen principios o criterios prácticos para la actuación del legislador particular de modo pastoralmente fecundo para el Pueblo de Dios.

Hizo a continuación una referencia, como punto bibliográfico, al examen de los índices, notas y comentarios de las dos ediciones españolas anotadas al nuevo Código ${ }^{35}$.

\section{C) El Derecho universal y particular en el nuevo Código de 1983}

1. Los presupuestos constitucionales son los siguientes:

a) Relación jerárquica de las competencias legislativas de los órganos de la Iglesia universal, como Romano Pontífice y Colegio Episcopal, la Curia Romana, etc. Es lo que suele llamarse De suprema Ecclessiae auctoritate. Siguen los órganos rectores de las «agrupaciones particulares», como los Concilios Particulares, Plenarios y Provinciales (cc. 439-446), Conferencia Episcopal (cc. 447-459) y el obispo diocesano (cc. 381 y 391 con 466 y otros). De esto se trató en el coloquio.

b) La ordenación de campos de competencia. Como se ve en lo doctrinal, disciplinar-sacramental, procesal y penal, hay competencias reservadas a favor de los órganos de la Iglesia universal «jure divino» y «jure positivo», como lo referente a la validez de los sacramentos (c. 841) etc.

c) Las reservas explícitas a favor de las Conferencias Episcopales aparecen en 88 cánones con otras referencias implícitas. Esto se trató más ampliamente en otra ponencia ${ }^{36}$.

d) Las reservas en favor de los obispos diocesanos. Esto también fue objeto de otras ponencias, especialmente en lo referente a la licitud de los sacramentos, como preparación matrimonial y Derecho litúrgico ${ }^{37}$.

2. La ordenación fundacional:

a) Las notas de la regulación canónica y la relación funcional en los tres niveles de competencia legislativa son apertura, fexibilidad y subsidiaridad, en lo que insistió Mons. Rouco Varela.

35. Además de los índices de la BAC y de EUNSA, se utiliza por los especialistas y estudiosos la obra de X. OCHOA, Index verborum ac locutionum Codicis Iuris Canonici, 2. ${ }^{\text {a }}$ edic. (Roma, Univ. Lateranense, 1984). Lo distribuye PPC, E. Jardiel Poncela, Madrid.

36. Esta materia fue objeto de la ponencia de Julio Manzanares.

37. La parte referente a los sacramentos y sacramentales lo veremos en la ponencia de José M. ${ }^{a}$ Díaz Moreno. Cf. A. Molina, «La potestad de los obispos (como Ordinarios) sobre los sacramentos», Revista Española de Derecho Canónico (REDC), 40 (1984) 5-14. 
b) La función o competencia legislativa de las Conferencias Episcopales y en menor grado de los Concilios particulares está situada entre los dos ejes principales de la constitución de la Iglesia: Santa Sede-Colegio Episcopal y obispo diocesano.

3. La definición legal del Derecho universal y particular:

a) La enseñanza del Concilio Vaticano II acerca de la constitución de la Iglesia en cuanto Iglesia universal con su Derecho nos hace ver que se comprende y encierra realmente, aunque también de un modo paradójico, en la dimensión particular, como «elemento constituyente» con su Derecho. Hay esencial identidad de notas referentes a la estructura interna, modo de producción del Derecho universal y particular, etc.

b) El c. 20, con novedad para la doctrina canónica del cese de la ley, tiene gran importancia según Mons. Rouco, aunque en gran parte es casi igual al c. 22 del Código de 1917, con respecto al Derecho particular.

c) Se nota la influencia del principio de subsidiaridad canónica en la formulación vigente del instituto de la dispensa, c. 87. Los obispos diocesanos no pueden dispensar de las leyes, que determinan elementos constitutivos esenciales de las instituciones o de los actos jurídicos (c. 86) ni de las leyes procesales y penales (c. 87).

Se nota la consagración definitiva del cambio posconciliar sobre esta materia.

El Derecho universal es el común a la Iglesia católica y el particular es el de la iglesia local o comunidad, que pudiera ser parroquial, sociedad religiosa etc.

D) Las características teológico-jurídicas del Derecho universal y particular con su sistema de relaciones

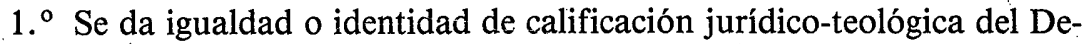
recho universal y del particular canónicos. Ambos vinculan en la vivencia de la comunión eclesial.

2. ${ }^{\circ}$ Hay una diferenciación o desigualdad en el grado y cualidad en la vinculación del Derecho universal y el particular, según su función dentro de la comunidad eclesial, constituyente o funcional, dependencia del jus divinum, próxima o remota.

3. ${ }^{\circ}$ Otras características son la amplitud y flexibilidad en la ordenación normativa de la relación de los dos Derechos en el actual ordenamiento canónico.

- Se da una regulación de mínimos orgánicos y funcionales con prevalencia 
del principio de subsidiaridad para evitar contradicciones y lograr cierta coordinación.

- La discrecionalidad es una nota típica del ejercicio de competencias legislativas por parte de los órganos de la Iglesia particular, singular y especialmente del obispo diocesano.

- La flexibilidad del nuevo Código y por tanto del Derecho universal vigente en la Iglesia latina favorece al desarrollo del Derecho particular con su terminología, conceptos y ordenación sistemática.

\section{E) Criterios canónico-pastorales para la praxis legislativa particular}

$1 .^{\circ} \mathrm{La}$ obediencia y comunión jerárquica, como marco básico del desarrollo legislativo particular, son fundamentales. El principio de «comunión jerárquica» es clave de unidad eclesial; pero no de unidad totalitaria. La obediencia tiene raíces evangélicas y jurídicas.

2. ${ }^{\circ}$ La coherencia básica de los objetivos pastorales con los de la Iglesia universal se basa en la peculiar naturaleza de las relaciones y vinculación de la Iglesia universal con la particular.

3. ${ }^{\circ}$ La sobriedad jurídica es un postulado, tanto de la subsidiaridad orgánica, como de la funcionalidad en la constitución de la Iglesia.

- Se ha reducido el número de cánones evitando la multiplicación de normas. A veces los árboles no dejan ver el bosque. No se pretende asfixiar con multitud de leyes, sino organizar la conducta de los fieles dentro de un marco de libertad y corresponsabilidad.

-El menor número de cánones del Código de 1983 está justificado con las remisiones al Derecho particular. Se nota una preocupación pastoral para favorecer la autonomía del Derecho particular.

4. ${ }^{\circ}$ Garantía y promoción de la comunión y bien común eclesiales —de la Iglesia universal y de la Iglesia particular-como justificantes e imperativós de la acción legislativa en la Iglesia particular.

$5 .^{\circ}$ Disponibilidad de medios técnicos - personales y materiales-, precisos para la producción legislativa y para el proceso de su aplicación y vivencia eclesiales.

Terminada la exposición de la ponencia se abrió un coloquio sobre el quehacer de los concilios particulares y sínodos diocesanos. Las experiencias de Alemania, Suiza, Holanda y otraš, se inspiran en la nueva Eclesiología, con mayor participación de los laicos, según normas aprobadas por la Santa Sede. Hay que tener en cuenta que el Código de 1917 era excesivamente clerical. El de 1983 da mayor participación a los laicos. Las experiencias han sido bastan- 
te buenas en parte y no son tan esperanzadoras como se pensó en los primeros años del posconcilio.

Sobre los concilios particulares tratan los cc. 439-446 con los plenarios y provinciales, que tienen su tradición en la Iglesia, lo mismo que los sínodos diocesanos (cc. 460-468). Su éxito depende mucho de la preparación.

La Conferencia Episcopal, como institución de carácter permanente y asamblea de los obispos de una nación o territorio determinado, suple en la praxis a los concilios particulares para promover una acción pastoral y común más eficaz, con función legislativa mediante los decretos generales, que se equiparan a leyes en su nación o territorio.

Mons. Rouco Varela reconoció que se estaban presentando algunas dificultades con la exención exigida por el c. 591 en atención a la utilidad común, para respetar y dejar a salvo las peculiaridades de cada instituto de vida consagrada. Con este fin, el Código de 1983 reconoce ciertos espacios autonómicos, como hemos visto anteriormente.

Las Conferencias de Superiores Mayores, que deben tener sus estatutos aprobados por la Santa Sede, están ayudando a solucionar no pocos problemas, coordinando las actividades mediante Secretaríados mixtos respecto a las Conferencias Episcopales y a los obispos en concreto para fomentar las mutuas relaciones y. salvaguardar la autonomía y fines peculiares de cada instituto.

\section{DERECHO PARTICULAR DE LA CONFERENCIA EPISCOPAL ESPAÑOLA}

A las 12 de la mañana del día 11 de abril, comenzó a exponer esta ponencia el profesor Julio Manzanares, que ha tratado ampliamente sobre esta materia en anteriores publicaciones ${ }^{38}$.

A manera de introducción observó que de jure, las Conferencias Episcopales no tienen una función propiamente legislativa, sino pastoral de acuerdo con el c. 447 para un trabajo concorde; pero de facto pueden dar sus decretos generales en los casos en que así lo prescriba el derecho común o cuando lo establezca un mandato especial de la Sede Apostólica, otorgado Motu proprio o a petición de la propia Conferencia (c. $455 \$ 1$ ). Estos decretos tienen validez y fuerza vinculante si se dan en reunión plenaria con dos tercios de los votos de los Prelados que pertenecen a la Conferencia con voto deliberativo y, «habiendo sido aprobados por la Sede Apostólica, son legítimamente promulgados» (c. $455 \S 2){ }^{39}$.

38. J. MANZANARES, «Las Conferencias Episcopales hoy. Configuración jurídica y fundamentos doctrinales», REDC, 35 (1969) 325-374 y otras.

39. Se pone en práctica la doctrina de Lumen gentium, n. 23 y Christus Dominus, n. 38. 
De esta manera se ejercita el munus regendi, es decir, la función de regir y de santificar por parte de la Conferencia Episcopal para que la ley canónica universal se adapte a las necesidades locales y pastorales de las diversas iglesias particulares, lográndose cierta armonía legal.

La Conferencia Episcopal Española viene tomando decisiones vinculantes desde 1964 con una experiencia positiva, que ha sido confirmada por el Código de 1983.

\section{a) Competencias atribuidas por Derecho común y ejercidas}

En el tratamiento del tema se prescindió de señalar los cánones y materias en donde la Conferencia Episcopal es mencionada, lo mismo que de dar un elenco de las facultades normativas o de indicar cuáles de esas facultades tienen carácter más urgentę. Se limitó a observar que las competencias de la Conferencia Episcopal eran mayores en los proyectos del Código hasta 1982, en que se hizo un recorte para salvaguardar cierta autonomía de los obispos diocesanos o iglesias locales. Su competencia incide en materia de liturgia, educación, matrimonios mixtos, patrimonio etc., por lo que sus decisiones suplen a las de los Concilios plenarios con posibilidad de actualización.

Hizo luego una breve reseña de la lista indicativa de la Secretaría de Estado, del Cardenal Casaroli (8-XI-1983) con 22 casos en los que podían legislar y 21 en los que debían legislar. Se dan unas normas en el Decreto transitorio del 25-XII-1983 y un primer Decreto general del 5-VII-1984 con las materias, revisión y promulgación, al que sigue un segundo Decreto general aprobado el 30XI-1984.

Se analizó el Decreto General de la Conferencia Episcopal Española, que reunida en Asamblea Plenaria (XXXIX) los días 21-26 de noviembre de 1983, en ejẹrcicio de su función pastoral respecto a los fieles de su territorio, decidió elaborar unas normas complementarias del Código de 1983.

El anterior Decreto tiene valor legislativo a tenor de los cc. 29-30 y desea proporcionar a la Iglesia española una legislación particular para evitar en lo posible que pueda paralizarse la actividad pastoral o cualquier desenvolvimiento de las relaciones entre los mismos fieles y entre éstos y la jerarquía. Se reconoce y observa que en unos casos su potestad consiste en determinadas atribuciones genéricas de competencia en relación a una determinada materia, lo cual no significa que esté ya obligada a legislar sobre ella de modo inmediato; en otros, se trata de una atribución de poder jurídico ante ciertas hipótesis. o condicionamientos prefijados, lo que no lleva consigo, como consecuencia,

Hay reservas a la Santa Sede, como todo lo referente a la validez de los sacramentos (c. 841), edición de libros litúrgicos y sacramentales (c. 838 \& 2), etc. 
el que deba ejercitarlo de modo inmediato, ni al mismo tiempo. Se requiere a veces cierta madurez, necesidad o urgencia para proceder a la promulgación de la legislación particular adecuada sin tardanza; en otras ocasiones será mejor esperar para poder legislar bien de cara al futuro.

Por estas razones, la XXXIX Asamblea Plenaria de la Conferencia Episcopal Española se reservó de momento, «dictar normas particulares sobre aquello a lo que refieren los cc. $230 \S 1 ; 755 \S 2 ; 766 ; 788 \S 3 ; 792 ; 844 \S \S 4$ y 5 ; $964 ; 1031 \S 3 ; 1112 \S 1 ; 1236 \S 1 ; 1251 ; 1265 \S 2 ; 1421 \S 2 ; 1425 \S 5 ; 1714 \mathrm{y}$ $1733 \S 2 \gg(\text { n. } 7)^{40}$.

En cambio tomó la decisión de «dar normas legislativas respecto a las materias jurídicas restantes sobre las que le han sido atribuidas facultades de legislar por los cánones del nuevo Código. De este modo, sin dilaciones, la legislación común de la Iglesia podrá presentarse completada en gran medida y por la legislación particular, quedando ésta armonizada con la universal»» (n. 8).

«Se ha de advertir, que en la legislación particular, junto a los preceptos totalmente nuevos, existen otros, que, por causa de lo dispuesto en el c. 3, han de limitarse a respetar lo pactado entre la Santa Sede y el Estado Español por aplicación de los Acuerdos del 3 de enero de 1979, a los que ha de hacer, en algunos casos, necesaria remisión».

«Así mismo, respecto a otras materias sometidas anteriormente a normas particulares procedentes de la propia Conferencia Episcopal, pueden éstas sancionarse (como de hecho se hace con algunas)... en estos casos, se hace en el articulado una referencia genérica a dicha normativa anterior al Código de 1983 (conforme al cual ha de interpretarse), otorgándole, mediante tal referencia, una fuerza legislativa según las exigencias del c. 455» etc. (nn. 9-10).

b) Articulado del Decreto general de la XXXIX Asamblea Plenaria

Art. 1

1. Los aspirantes al Diaconado Permanente recibirán la adecuada formación, a tenor de lo dispuesto en el c. 236, según las normas aprobadas por la Conferencia Episcopal en su XXVII Asamblea Plenaria (21-26 noviembre de 1977) y que ahora se ratifican ${ }^{41}$.

2. A tenor del c. $242 \S 1$ sobre el plan de formación sacerdotal para Seminarios Mayores, se confirma lo ya establecido precedentemente (XXVII Asamblea Plenaria). (El plan de formación sacerdotal fue aprobado por la Sa-

40. CONFERENCIA EPisCopAl EsPañola, «Decreto general», Boletín, 3 (1984) 98-99. Se trata del primer Decreto general de la misma.

41. Ibid., pp. 99 y 105-110 donde está el anexo 1 . 
grada Congregación para la Educación Católica el 25 de noviembre de 1978 y deberán acomodarse a él los Institutos religiosos en sus planes de formáción).

3. Los diáconos permanentes celebren la liturgia de las horas en la que se unen a toda la Iglesia en la alabanza a Dios y en la oración por la salvación del mundo. Su obligación, sin embargo, se limita a Laudes y Vísperas, de acuerdo con las facultades reconocidas en el c. $276 \S 2,3 .^{\circ}$.

Art. 2

Usen los clérigos traje eclesiástico digno y sencillo, sotana o clergyman; según las costumbres legítimas del lugar, a tenor del c. 284 , especialmente en el ejercicio del ministerio sacerdotal y en otras actuaciones públicas.

Art. 3

A tenor del c. 496 , en lo relativo a los Estatutos del consejo presbiteral se tendrán en cuenta las normas siguientes:

$\S 1$. Respecto a los miembros del consejo presbiteral:

1. ${ }^{\circ}$ Los Estatutos podrán establecer otros criterios de representatividad además de los expresados en el c. 499;

$2 .^{\circ}$ entre los miembros natos habrán de figurar en todo caso:

-el Vicario(s) General(es);

-el Vicario(s) Episcopal(es);

-el Rector del Seminario Mayor;

-el Presidente del Cabildo Catedral.

$33^{\circ}$ El número total de miembros nombrados por el obispo y de miembros natos no excederá en todo caso del 50 por 100 de los miembros del consejo presbiteral.

4. ${ }^{\circ}$ Los Estatutos determinarán los oficios que se ejercen en bien de la Diócesis por parte de sacerdotes seculares no incardinados, así como de miembros de Institutos religiosos o de Sociedades de vida apostólica (c. $498 \S 1$ ).

$\S 2$. Debe cuidarse que:

1. ${ }^{\circ}$ Para ejercer el derecho de elección de miembros para el consejo presbiteral, nadie tenga más de un voto, aunque pertenezca a más de un grupo;

para ejercer el derecho de voto dentro del consejo presbiteral nadie tenga más de un voto, aunque fuera miembro del consejo por títulos diversos.

$\S 3$. El elegido por un grupo, si bien normalmente ha de consultar a sus representados el tratamiento de los temas que figuran en el orden del día, emite su voto bajo la propia personalidad y no como mero portavoz de sus electores. 
$\S 4$. 1. Además de las prerrogativas y competencias expresamente atribuidas al consejo presbiteral por el Código (cc. $443 \S 5 ; 463 \S 1 ; 515 \S 2 ; 1263$; 1742), los Estatutos determinarán algunas cuestiones de gobierno y asuntos de mayor importancia en los que el obispo debe consultar al consejo presbiteral. (Estas disposiciones se están incorporando a los Estatutos de los distintos consejos presbiterales o se implementan a la hora de renovarlos).

2. Caso de existir en la Diócesis el consejo pastoral, corresponde al consejo presbiteral deliberar acerca de las medidas adecuadas de gobierno que se deduzcan del estudio, valoración y sugerencias hechas por el consejo pastoral según el c. 511, de acuerdo con lo que establezcan los Estatutos y disponga el obispo de la Diócesis.

$\S 5$. 1. Los Estatutos determinarán que, al convocarse el consejo a tenor del c. $500 \S 1$, se comunique con la suficiente antelación el orden del día. 2. Es competencia exclusiva del obispo diocesano la publicación y divulgación de lo tratado y acordado en el consejo presbiteral.

Art. 4

A tenor del c. 522, puede el obispo diocesano nombrar párrocos para un tiempo determinado, generalmente no inferior a seis años, renovables si así lo exige el bien de las almas. (Se trata de la facultad, que la Conferencia Episcopal concede a los obispos para nombrar párrocos ad tempus. De tal facultad puede hacer uso el obispo diocesano cuando así lo considere oportuno; pero no es para él una ley obligatoria o vinculante, sino opcional).

Art. 5

En lo que se refiere a la autorización que contiene el c. $535 \S 1$, síganse las normas, vigentes hasta ahora, relativas a los libros parroquiales, incluso el Libro-Registro de confirmaciones tal como se viene utilizando en la práctica parroquial. Además cuiden los párrocos de cumplir personalmente el deber de notificación que ordena el c. 895. (Se urge el Libro parroquial de confirmaciones).

Art. 6

Respecto a la competencia legislativa otorgada por el c. $538 \S 3$, sobre la conveniente sustentación y vivienda de los sacerdotes jubilados, se estará a lo dispuesto por las normas anteriores de la Conferencia Episcopal, vigentes en la fecha de promulgación del Código.

(En España, a partir de los 65 años cumplidos, todo sacerdote que haya hecho la correspondiente cotización, puede solicitar la jubilación dentro del sistema de la Seguridad Social del clero; pero quẹda a juicio del obispo el dar 
trámite o no a la solicitud. Deberá aceptar dicha jubilación, una vez llegado a los 70 años de edad).

Art. 7

1. De conformidad con lo establecido en el c. $775 \S 2$, sígase lo ya dispuesto al respecto por la Conferencia Episcopal (sobre catecismos).

2. En cumplimiento de lo previsto en el c. $804 \S 1$, manténgase asimismo lo que fue establecido por la Conferencia Episcopal para la formación y educación religiosa en las escuelas y por las normas estipuladas en el Acuerdo entre la Santa Sede y el Estado Español sobre enseñanza y asuntos culturales, juntamente con las disposiciones convenidas que las desarrollan.

Art. 8

1. Respecto a las traducciones de los libros litúrgicos a las lenguas vernáculas y su posterior edición, en observancia al c. $838 \S 3$, sigue vigente lo que en su momento se determinó por la Conferencia Episcopal.

2. Asimismo, en cumplimiento de los cc. 841 y $851, \mathrm{n} .^{\circ} 1$, se ha de estar a lo que se dispuso en los Libros Rituales de los Sacramentos, debidamente aprobados por esta Conferencia Episcopal, y a lo que se prescribe en los artículos 10 y 11 de este Decreto, en observancia de los cc. 891 y 1083 respectivamente, sobre la edad para recibir la confirmación y de contraer matrimonio.

3. En relación con lo ordenado por el c. 854 , sígase la costumbre extendida en España del bautismo por infusión tal como se recoge en el Ritual aprobado al efecto por esta Conferencia Episcopal.

Art. 9

En observancia con lo se dispone en el c. 877 § 3, los párrocos deben cuidar que en las inscripciones de un hijo adoptivo en el Libro de los bautizados, se haga constar el nombre o nombres de sus adoptantes, y que en dicha inscripción consten además los otros datos que recoja la inscripción de adopción efectuada en el Registro Civil, a cuyo efecto el párroco exigirá antes de proceder a la inscripción en el Libro de bautizos, el oportuno documento del Registro Civil que certifique legítimamente la adopción practicada. (En esta materia hay que tener en cuenta también las disposiciones del ordenamiento civil, evitando las expresiones difamantes).

Art. 10

En uso de las facultades reconocidas en el c. 891, se establece como edad para recibir el sacramento de la confirmación la situada (en general) en torno a los 14 años, salvo el derecho del obispo diocesano a seguir la edad de la discreción a la que hace referencia el canon. (Cada obispo en su diócesis puede 
precisar mejor la edad de la discreción para lograr una mayor madurez y preparación).

Art. 11

No podrán contraer lícitamente matrimonio el varón y la mujer, que no hayan cumplido 18 años. (Esto equivale a un impedimento impediente).

Art. 12

1. Para dar cumplimiento al c. 1067, hágase un expediente matrimonial, que incluya el examen de los contrayentes y de los testigos indicados en el Ane$x o\left(2 .^{\circ}\right)$ de este Decreto ${ }^{42}$.

2. Además publíquense las proclamas por edicto fijado en las puertas de las iglesias por un plazo de quince días o, donde haya tradición de ello, léanse las proclamas habituales al menos en dos días de fiesta.

3. Las declaraciones y promesas, que preceden a los matrimonios mixtos y a las que hace referencia el c. 1126, se ajustarán a lo dispuesto en las normas dictadas por esta Conferencia Episcopal el 25 de enero de 1971, para la aplicación en España del Motu proprio Matrimonia mixta.

Art. 13

1. Autorizada la Conferencia Episcopal por el c. $1246 \S 2$ para suprimir o trasladar a domingo algunas de las fiestas de precepto, sigue vigente lo convenido por esta Conferencia en aplicación de lo previsto en el art. III del Acuerdo entre la Santa Sede y el Estado Español sobre asuntos jurídicos.

2. A tenor del c. 1253 , se retiene la práctica penitencial tradicional de los viernes del año consistente en la abstinencia de carnes; pero puede ser sustituida, según la libre voluntad de los fieles por cualquiera de las siguientes prácticas recomendadas por la Iglesia: Lectura de la Sagrada Escritura, limosna (en cuantía que cada uno estime en conciencia), otras obras de caridad (visita de enfermos o atribulados) obras de piedad (participación en la santa misa, rezo del rosario etc.) y mortificaciones corporales.

En cuanto al ayuno, que ha de guardarse el Miércoles de Ceniza y el Viernes Santo, consiste en no hacer sino una sola comida al día; pero no se prohíbe tomar algo de alimento a la mañana y a la noche, guardando las legítimas costumbres respecto a la cantidad y calidad de los alimentos.

Art. 14

1. En lo relativo a los cc. 1262,1272 y 1274 , se estará a lo que se estipula en el Acuerdo entre la Santa Sede y el Estado Español sobre asuntos económi-

42. Ibid., pp. 103 y 111-113, donde aparece el anexo 2. 
cos, y a las disposiciones convenidas que lo desarrollan, así como a las normas especiales aprobadas por la Santa Sede el 19 de junio de 1981, prorrogadas por un año por el Romano Pontífice, en audiencia del 5 de noviembre de 1983.

2. A efectos del c. 1292 se fija como límite mínimo la cantidad de cinco millones (5.000.000) de pts., y el límite máximo la de 50.000.000 de pts. (el límite máximo de los 50 millones se aplica también a los religiosos y Sociedades de vida apostólica según Rescripto del 5-XI-1984) ${ }^{43}$.

3. El arrendamiento de bienes rústicos y urbanos, comprendidos en el c. 1297 , se equipara a la enajenación en cuanto a los requisitos para su otorgamiento.

\section{Disposición final:}

En cumplimiento de lo dispuesto en el c. $8 \S 2$, se promulgará el presente Decreto general en el Boletín Oficial de la Conferencia Episcopal Española. Este Decreto comenzará a obligar a partir de la fecha de su promulgación. Todas las normas que esta Conferencia elabore en el futuro serán promulgadas en dicho Boletín.

\section{Normas transitorias:}

1. En aplicación del c. 502, se dispone que, en tanto no pueda ser constituido el Colegio de Consultores, de acuerdo con lo prescrito en el párrafo 1 de dicho canon, su función sea ejercida por el Cabildo Catedral, conforme a las normas del Código de 1917. Esta función transitoria cesa necesariamente el 1 de enero de 1985.

2. Respecto a las materias de los cc. $772 \S 2 ; 804 \S 1$ (sólo en lo que se refiere a los medios de comunicación social), $831 \S 2,1062 \S 1$ y 1277 , hasta el $1 .^{\circ}$ de enero de 1985 se estará a lo que dispone el Código de Derecho Canónico de 1917. Madrid, 26 de noviembre de 1983.

c) Competencias ejercidas con mandato especial y otras no ejercidas

Entre las competencias ejercidas con mandato especial está el Decreto aprobado el 30-XI-1984, que tiene un antecedente en el Decreto del 22-VIII1981. Está colaborando el Secretariado Nacional de Liturgia ${ }^{44}$.

Se pensó en tres decretos o documentos, dada la diversidad de la materia,

43. F. CAMPo DEL Pozo, «El Derecho Patrimonial de los Institutos de Vida Consagrada», Rev. Confer, 33 (1984) 479-532. Con ocasión de este trabajo, la CONFER formuló la correspondiente petición a la Sagrada Congregación de Religiosos e Institutos seculares.

44. El Secretariado Nacional de Liturgia elaboró un Directorio litúrgico pastoral sobre el ministerio de lector y su formación en 1984. Cf. Boletín Oficial del Arzobispado de Valladolid, 109 (1985) 302-346. 
sobre condiciones para que se pueda permitir la predicación de laicos, sede para oír confesiones, materia del altar, etc.; pero se optó por reducirlo a uno con 16 artículos ${ }^{45}$.

Se va reorganizando la economía con la fijación de una dote básica, que ayudará a la vida económica de la Iglesia en España.

Hay algunas materias aplazadas como lo referente a los esponsales, administración de sacramentos a cristianos no católicos etc.

En general, la Conferencia Episcopal Española ha actuado bastante bien y a tiempo, uniformando criterios y actuando con prudencia. En algunos casos se ha optado por dejarlo a la discreción de los obispos dảdas las diferencias culturales, que exigen adaptación e inculturación.

Sus decisiones están siendo bien recibidas por los clérigos, a los que les ha interesado más lo referente a la economía, valorando de un modo positivo el Derecho particular de la Confêrencia Episcopal y de sus peritos.

\section{CONSEJOS PRESBITERALES Y COLEGIOS DE CONSULTORES}

Esta ponencia fue expuesta por Luis Martínez Sistach el día 11 a las cinco de la tarde, comenzando por hacer una introducción sobre los antecedentes, su método de trabajo para explicitar las matizaciones de los distintos estatutos y su ubicación en el Derecho común y particular.

\section{Los consejos presbiterales y sus antecedentes}

Se trata de una institución nueva, como el colegio de consultores, que tiene antecedentes en los primeros siglos. Se habla de los presbíteros, como senado y consejeros del obispo ${ }^{46}$. Unos 38 estatutos de Consejos presbiterales en España recogen la idea de que se trata del senado del obispo.

Su creación y delineamientos aparecen en el Concilio Vaticano II, como un organismo consultivo compuesto por sacerdotes diocesanos y religiosos, que de algún modo están subordinados a la jurisdicción de los obispos diocesanos ${ }^{47}$.

Antes del Código de 1983 aparecieron algunas normas sobre la obligatoriedad de este organismo, como senadó consultivo y respresentante de los

45. El segundo Decreto general fue aprobado por la Santa Sede el 8-VI-85 y publicado en el Boletín de la Conferencia Epis. Esp., 6 (1985) 60-65. En las pp. 67-69 aparece un Decreto general sobre materia económica.

46. S. Ignacio De Antioquía, Epistola ad Trallianos, 3, 1 (PL 5, 678); S. Cipriano, Epistola, 4 (PL 4, 30), etc. Cf. F. CAMPo, Pastoral de conjunto de clérigos y religiosos según S. Agus: tín y el Concilio Vaticano II», Estudio Agustiniano, 11 (1976) 473-475.

47. Lumen gentium, nn. 28 y 44; Christus Dominus, nn. 34-35. 
presbíteros, que pueden ayudar eficazmente al obispo con sus consejos. Lo debe presidir el obispo y va a suplantar funciones que venía ejerciendo el Cabildo catedralicio ${ }^{48}$.

a) Disposiciones del Código de 1983 sobre el consejo presbiteral

No se hizo una exposición de los cc. 491-501, porque se suponía que era materia conocida de los asistentes, limitándose a resaltar algunas ideas claves. $\mathrm{Su}$ obligatoriedad, concepto y finalidad aparece en el c. $495 \S 1$. Debe haber un consejo presbiteral también en los vicariatos y prefecturas apostólicas, constituido al menos por tres misioneros, de los que reciba parecer, incluso por carta, en los asuntos más graves (c. $495 \S 2$ ).

Cada consejo presbiteral debe tener sus estatutos con aprobación del obispo diocesano, «teniendo en cuenta las normas que haya dado la Conferencia Episcopal» (c. 496). La presidencia la tiene el obispo, a quien corresponde el convocarlo y determinar las cuestiones que deben tratarse o aceptar las que propongan los miembros (c. $500 \S 1$ ).

En cuanto a los miembros y su designación según el c. 497:

-la mitad de sus miembros deben ser elegidos libremente;

-hay algunos miembros natos por el oficio, que tienen encomendado;

-el obispo tiene facultad de nombrar otros miembros.

Sobre sacerdotes con derecho activo y pasivo de elección (c. 498):

$1 .^{\circ}$ todos los sacerdotes seculares incardinados en la diócesis;

$2 .^{\circ}$ los no incardinados, los religiosos o miembros de Sociedades de vida apostólica, que residan allí o tengan algún oficio;

3. ${ }^{\circ}$ según los estatutos, otros sacerdotes, que tengan domicilio o cuasi domicilio en la diócesis ${ }^{49}$.

En cuanto a las competencias del consejo presbiteral, con voto consultivo, se observó que, de acuerdo con el c. $500 \S 2$, debe oírlo en los asuntos de mayor importancia, unos cinco casos. El consejo presbiteral nunca puede proceder sin el obispo diocesano, que es el único que puede autorizar para divulgarlo (c. $500 \S 3$ ).

La duración depende de lo determinado en los estatutos con la condición de que todo el consejo o parte de él se renueve cada cinco años. Cesa al quedar la sede vacante. El nuevo obispo debe constituirlo en el plazo de un año. Si deja de cumplir su función o abusare de ella, el obispo, después de consultar al

48. Sagrada Congregación Para El Clero, Circular del 11 de abril de 1970, AAS, 62 (1970) 359-465.

49. Communicationes, 14 (1982) 216. En cuanto a los miembros natos hay que tener en cuenta lo establecido por la Conferencia Episcopal. 
Metropolitano o sufragáneo más antiguo, puede disolverlo; pero ha de constituirlo de nuevo en el plazo de un año (c. 501 §§ 1-3).

\section{b) Normas de la Conferencia Episcopal Española}

No trató Luis Martínez Sistach lo referente a la Conferencia Episcopal Española, porque era objeto de la ponencia de Julio Manzanares, que hemos visto anteriormente.

La Conferencia Episcopal Española dio algunas orientaciones en el año 1966 durante la asamblea general celebrada ese año en noviembre ${ }^{50}$. Después de la promulgación del Código de 1983, haciendo uso de las facultades, que le confiere el c. 496, en su primer Decreto general del 26 de noviembre de 1983, estableció que se dejan los criterios de representatividad a los estatutos, teniendo en cuenta que en todo caso se han de considerar miembros natos a los Vicarios Generales y Espiscopales, Rector del Seminario y Presidente del Cabildo catedralicio.

Los miembros natos y los elegidos por el obispo diocesano no deben pasar de la mitad. Se debe determinar en los estatutos, qué oficios y número de religiosos. Debe cuidarse de que se tenga un voto, aunque represente a varios grupos. A la hora de votar u opinar debe hacerlo líbremente, aunque teniendo en cuenta la opinión de los electores, a los que debe informar dentro de lo posible.

Es necesario comunicar con la debida antelación el orden del día. En los estatutos se pueden precisar otros detalles. Existe el consejo presbiteral en todas las diócesis españolas. Unas tienen los estatutos elaborados por ellas mismas, otras se rigen por las normas dadas por el Obispo y la Conferencia Episcopal.

Se informó sobre la marcha de los consejos presbiterales en España con una valoración positiva. En general funcionan bien y están prestando valiosa ayuda a los obispos.

\section{Colegio de consultores}

Esta materia, que ha sido tratada ampliamente por Luis Martínez Sistach, tiene los mismos antecedentes que el consejo presbiteral ${ }^{51}$. Se trata también de una institución nueva, que no coincide con los consultores diocesanos del Código de 1917 (cc. 423-428) ni con los párrocos consultores (cc. 385-390) del mismo Código.

50. Ecclesia, 66 (1966) 2649-1260.

51. L. MARTíneZ SiSTACH, «El colegio de consultores en el nuevo Código», REDC, 39 (1983) 291-305. 
Está ubicada en el libro II del Código de 1983, titulado Del Pueblo de Dios y, más en concreto, dentro del título $3 .^{\circ}$ (De la ordenación interna de las Iglesias particulares), sección segunda de la segunda parte (De la constitución jerárquica de la Iglesia). Por tratarse de una institución diocesana, la diócesis es el contexto adecuado para el tratamiento del colegio de consultores.

\section{a) Un organismo vinculado al consejo presbiteral.}

Insistió L.M. Sistach en la ubicación del colegio de consultores en el Código de 1983 (c. 502) para hacer ver su vinculación al consejo presbiteral, por lo que participa de su naturaleza, para prestar un servicio a la diócesis en algunos asuntos más importantes o que hay que guardar secreto y especialmente al cesar el consejo presbiteral durante la sede vacante. De ahí que ambas instituciones tienen distinta justificación y difieren por razón de sus competencias, su constitución y permanencia.

Se trata de un organismo sacerdotal, como el presbiteral, de entre cuyos miembros el obispo nombra algunos sacerdotes libremente. Su número no debe ser inferior a seis, ni superior a doce, «que constituyen durante cinco años el colegio de consultores, al que competen las funciones determinadas por el derecho; sin embargo, al cumplirse el quinquenio, sigue ejerciendo sus funciones propias en tanto no se constituya un nuevo consejo» (c: $502 \S 1$ ).

El colegio de consultores tiene funciones de gobierno, que ejercía antes el capítulo o Cabildo catedralicio y no se le atribuyen al consejo presbiteral, sino a esta nueva institución. De ahí que la Conferencia Episcopal pueda establecer que sus funciones se encomienden al Cabildo catedralicio (c. 502 \&).

Dada la conexión al consejo presbiteral, se dudó si, al cesar un miembro del consejo presbiteral, seguía o podía permanecer en su oficio de consultor. L. Martínez Sistach defendía que sí y le ha dado la razón la Comisión Pontificia para la Interpretación aủténtica del Código de Derecho Canónico de 1983 el 26 de junio de 1984. Se mandó publicar el 11 de julio del mismo año, aclarando también que si el obispo diocesano, cesa a un consultor en su cargo durante el quinquenio, no tiene obligación de nombrar otro, a no ser que falte el mínimo de seis miembros requeridos por el c. $502 \S 152$.

\section{b) Presidencia del colegio de consultores y sus funciones}

Según el c. 502 \& 2, «preside el colegio de consultores el obispo diocesano; cuando la sede está impedida o vacante, aquel que provisionalmente hace las veces del obispo o, si éste no hubiera śido constituido, el sacerdote más anti-

52. Pontificia Commissio Codicis Iuris CANONICI AUTHEnTICAE INTERPRETANDo; «Responsa ad proposita dubia», AAS, 76 (1984) 746-747. 
guo en ordenación de los miembros del colegio de consultores». Se potencia así el ministerio episcopal en la Iglesia diocesana.

No se trata de un organismo representativo, aunque tiene este carácter subsidiariamente. Funciona colegialmente y decide por mayoría absoluta de los presentes. Aunque suele ser consultivo, en ocasiones su dictamen es vinculante, como se exige en los cc: 27.2 y 485 , siendo muchos los casos en los que debe ser preceptivamente consultado por el obispo diocesano. Así, por ejemplo, debe oír al colegio de consultores para nombrar el ecónomo diocesano o para removerlo (c. $494 \S \S 1-2$ ). El ecónomo puede formar parte del colegio de consultores, si es presbítero; pero se excluye si es un laico.

«Por lo que se refiere a la realización de actos de administración que, atendida la situación económica de la diócesis, sean de mayor importancia, el obispo diocesano debe oír al consejo de asuntos económicos y al colegio de consultores... necesitando el consentimiento de los mismos para realizar actos de administración extraordinaria» (c. 1277). Necesita su consentimiento en casos de enajenación que supere el mínimo señalado por la Conferencia Episcopal según el c. 1292.

\section{c) Papel del colegio de consultores en sede vacante}

Como ya se hizo notar anteriormente, al cesar el consejo presbiteral, durante la sede vacante, asume sus funciones el colegio de consultores (c. 501 $\S 1)$.

Al quedar la sede vacante, si no hay obispo auxiliar, el gobierno de la diócesis pasa al colegio de consultores, a no ser que la Santa Sede hubiera establecido otra cosa (c. 419). «El Administrador diocesano, es decir, el que ha de regir temporalmente la diócesis, debe ser elegido por el colegio de consultores antes de los ocho días a partir del momento en que éste reciba la noticia de la vacante de la sede» (c. $421 \S 1$ ) a no ser que la Conferencia Episcopal haya encomendado èsta función al Cabildo catedralicio (c. $502 \S 3$ ).

El Administradơr diocesano, según el c. 272, nò puede conceder la excardinación o incardinación, ni tampoco la licencia para trasladarse a otra Iglesia particular, a no ser que haya pasado un año desde que quedó vacante la sede episcopal, y con el consentimiento del colegio de consultores.

La perioricidad de las reuniones depende del obispo diocesano y de las materias que se presenten. El coloquio fue clarificador.

\section{LOS CABILdos CATEDRALÍ́cIOS Y EL CONSEJO DE PASTORAL}

Después de la ponencia sobre «Consejos presbiterales y colegios de consultores, se desarrolló otra el mismo día 11 de abril a las 7 de la tarde sobre 
«Cabildos catedralicios» por Ramón García, Vicario Judicial del Arzobispado de Oviedo.

En una breve introducción expuso la importancia de esta institución en el pasado. Se tomó bastante en cuenta al cabildo en el Código de 1917 gracias al cardenal Gasparri. Durante el Concilio Vaticano II se pidió la puesta al día de esta institución ${ }^{53}$. Posteriormente se suprimieron en 1970 algunas de sus insignias y privilegios ${ }^{54}$.

\section{a) El Cabildo catedralicio en el Código de 1983}

Se dedica al cabildo los cc. 503-510, sobre los que se hizo una exposición de su contenido y una valoración, que se extendió también a los informes recibidos. Según el c. 503 la actividad del cabildo se va a reducir a la celebración de «las funciones litúrgicas más solemnes de la iglesia catedral o en la colegiata». El obispo diocesano les puede encomendar otros oficios. Dada la falta de vitalidad en la mayoría de los Cabildos catedralicios, algunos piensan que ha llegado la hora de su supresión, como se ha hecho en algunas partes; pero esto queda reservado a la Santa Sede (c. 504). Lo importante es actualizarlos mediante los nuevos estatutos (cc. 505-506). Se ha tendido a un estatuto marco y a la defensa de los derechos adquiridos. Esto no se ha aceptado por el Episcopado español.

En todo cabildo debe quedar uno que presida y se determinarán también otros oficios de acuerdo con los estatutos «teniendo en cuenta el uso vigente de cada nación» (c. 507). Un puesto u oficio importante es el de penitenciario, que tiene facultad ordinaria, no delegable, para absolver en el fuero sacramental de las censuras latae sententiae, «no declaradas, ni reservadas a la Santa Sede» (c. 508 \& 1). Si no hay cabildo, el obispo diocesano pondrá un sacerdote para que cumpla la misma función (c. 508 \& 2).

El obispo debe conferir las canonjías tan sólo a sacerdotes destacados por su doctrina e integridad de vida, oído el cabildo (c. $509 \S \S 1-2$ ). En el c. 510 se dan pautas para atender a las necesidades pastorales, pudiéndolo convertir en un centro de orientación pastoral.

\section{b) Derechos y deberes de los capitulares}

Prescindiendo de la incorporación al cabildo, su toma de posesión y cese, sobre lo que se hizo un breve resumen, se resaltó que al suprimirse el sistema

53. Christus Dominus, n. 27.

54. Sagrada Congregación para El Clero, Carta circular del 30 de octubre de 1970, AAS, 63 (1970) 314. 
beneficial o tenderse hacia ello, se ha aplicado un régimen transitorio, sin que se hayan respetado siempre los derechos adquiridos. Su situación era en parte insostenible. Su retribución actual es poca. No tiene sentido el oficio coral en iglesias vacías y con malos cantores. Algunos ancianos, ya jubilados, quieren seguir participando en el canto. Es mejor partir del sueldo base con los complementos pertinentes.

El Código de 1983 ya no exige, ni recomienda el oficio diario; pero puede seguir y en algunas catedrales se hace bien o se puede reducir a ciertos días y solemnidades con participación de los fieles en otras.

Una de las mayores funciones y responsabilidades del cabildo es la conservación y administración del patrimonio catedralicio o colegiata. Esto hay que armonizarlo dentro de la diócesis.

Tanto los derechos como los deberes se suelen explicitar en los estatutos. El ponente había pedido informes a 76 cabildos y contestaron 63 al cuestionario. En las respuestas se nota cierto desaliento, al no ver un porvenir esperanzador al cabildo. El éxito de los cabildos durante la Edad Media, especialmente de los Canónigos de San Agustín, se debió a su acomodo a las exigencias de aquella época. Quizás sea necesario hacer hoy lo mismo o dejar que poco a poco vayan desapareciendo. Su porvenir se ha dejado en manos de los obispos ${ }^{55}$.

\section{c) El consejo pastoral diocesano}

El día 12 de abril, a las 10 de la mañana, expuso brillantemente su ponencia Ángel Marzoa, profesor de Filosofía del Derecho en la Universidad de Navarra sobre «Consejos pastorales diocesanos e infradiocesanos».

En una breve introducción se refirió a los antecedentes de esta institución nueva, como organismo consultivo para asesorar en lo pastoral al obispo diocesano o a los que hacen sus veces coordinando algunas actividades. Se trata de esta materia en los cc. 511-514 del Código de 1983, que recoge la normativa del Concilio Vaaticano II y legislación posconciliar ${ }^{56}$.

No ha tenido el éxito que se preveía con las Normas orientadoras de la Conferencia Episcopal Española en 1966, ni con la Carta circular de la S. C. del Clero en 1973, como se constata en las respuestas formuladas a los consejos pastorales diocesanos existentes en España. Se espera una renovación con el Código de 1983 al insistir en su importancia y oportunidad con la participa-

55. En España se promovió a partir de 1970 la Asociación de los cabildos españoles y se elaboró un Estatuto marco para revitalizarlos sin efectos positivos. Se ha pasado de 32 cánones a 8 en el Código de 1983.

56. Cristus Dominus, n. 27 y Ecclesiae sanctae, I, 16-17. 
ción de los laicos. Se sigue poniendo énfasis en su asesoramiento para estudiar y valorar lo que se refiere a las actividades pastorales. No es obligatorio, sino que se recomienda, diciendo que se «constituirá en cada diócesis, en la medida en que lo aconsejen las circunstancias» (c. 51.1).

Los miembros deben ser idóneos, que destaquen por su fe, buenas costumbres y prudencia (c. $512 \S 3$ ). Hay diversos criterios sobre elección, número de miembros, representación, funciones, que en parte están señaladas, convocatoria y reunión, que dependen del obispo diocesano y los estatutos por él aprobados (c. $513 \S 1$ ). Se ha de reunir por lo menos una vez al año (c. 414 $\S 2$ ). Lo preside el obispo diocesano (c. $514 \S 1$ ).

El poco éxito y fracaso de algunos consejos pastorales se ha debido a la extrapolarización de sus funciones. El presbiterio ha venido asumiendo algunas de sus funciones pastorales. Ha existido cierto recelo en cuanto a la participación de los religiosos y los laicos. Esto ya se notaba en $1970{ }^{57}$. Se espera una incentivación con el nuevo Código.

\section{d) El consejo pastoral infradiocesano}

Mayor éxito están teniendo los consejos pastorales parroquiales, que tienen sus precedentes en las juntas parroquiales y se recomiendan en el c. 536: «Si es oportuno, a juicio del obispo diocesano, se constituirá en cada parroquia, oído el consejo presbiteral, un consejo pastoral, que preside el párroco y en el cual los fieles, junto con aquellos que participan por su oficio en la cura pastoral de la parroquia, presten su colaboración para el fomento de la actividad pastoral». Debería dejarse su establecimiento al criterio del párroco, que conoce mejor las condiciones de su parroquia. En esto pueden colaborar los Arciprestes.

:El control episcopal se nota en el mismo c. 536 § 2: «El consejo pastoral tienen voto consultivo, y se rige por las normas que establezca el obispo diocesano!». A veces conviene que exista un consejo pastoral en el arciprestazgo, otras en la zona. Hay sacerdotes que atienden a varios pueblos o parroquias y pueden establecer uno o más consejos.

Los religiosos, que trabajan en colegios $u$ otras actividades, deben tener su participación, lo mismo que los Institutos seculares. Los 20 años del postconcilio son todavía pocos para ver si esta institución ha madurado o no.

Es necesario potenciar el consejo pastoral parroquial dados sus condicionamientos. Se permiten los consejos infradiocesanos y supraparroquiales, mientras que se prohíben los supradiocesanos.

57. J. CASTEX ANAYA, El consejo pastoral en las diócesis españolas (Madrid 1970) 352 pp: Cf. F. CAMPO, «Pastoral de conjunto»; pp. 486-489. 
Se han formulado preguntas sobre el estado y porvenir del consejo pastoral infradiocesano o parroquial después del Código de 1983. Según Ángel Marzoa, que realizó la encuesta, los datos son escasos para poder sacar conclusiones o formulaciones sobre ellos. Más bien se hacen consideraciones generales. Algunos decían que no se ha llegado a entender bien su finalidad y funciones.

$\mathrm{Al}$ existir un consejo pastoral diocesano, sin los consejos pastorales parroquiales, se convertía en ineficaz. Se ha intentado, por eso, partir en algunas diócesis desde abajo, por los consejos parroquiales, para lograr mejor representatividad.

En el coloquio abundaron las opiniones, como la de que era necesario crear conciencia de participación, facilitar mayor autonomía a los laicos, etc. Otros opinaban que esta institución puede tener mucho éxito de cara al futuro. Se ha tratado sobre la corresponsabilidad en el XIII Coloquio Europeo de Parroquias celebrado en Tarragona del 1 al 5 de julio de 1985.

\section{CONSEJO-DE ASUNTOS ECONÓMICOS Y ASOCIACIONES DE FIELES}

Esta materia fue objeto de dos ponencias desarrolladas por canonistas andaluces, muy competentes y especialistas en esta problemática. La primera titulada «Consejos de asuntos económicos y creación de fondos comunes», la tuvo José M. ${ }^{a}$ Piñero Carrión ${ }^{58}$ el día 12 a las 12 de la mañana y la segunda, "Asociaciones públicas y privadas de fieles», Francisco Vera Urbano, catedrático de Derecho Canónico en la Universidad de Málaga, el mismo día a las 5 de la tarde.

Los dos temas son merecedores de un amplio trabajo, especialmente el económico, aunque aquí nos limitaremos a una breve reseña.

\section{Consejos de asuntos económicos y creación de fondos comunes}

a) El consejo de asuntos económicos en cada diócesis

Se trata de una institución nueva e importante con la figura del ecónomo diocesano (c. 492 \& 1). Existía un anticipo en el c. 1520 del Código de 1917 al hablar de un consejo de administración. Sin embargo, la figura del ecónomo, tal comó aparece en el Código de 1983, nace en el Concilio. Vaticano II, al iniciarse la reforma del Derecho patrimonial ${ }^{59}$.

58. J. M. ${ }^{\text {a }}$ PIÑERo CARrIón, «Consecuencias internas, en la Iglesia, del nuevo sistema económico», en El hecho religioso en la nueva Constitución española (Salamanca, Instituto S. Raimundo de Peñafort, 1979) 355-405; El dinero de la Iglesia, en qué se gasta, quién lo da, cómo se administra (Salamanca, Universidad Pontificia, 1980), $155 \mathrm{pp}$.

59. Apostolicam actuositatem, n. 10 y Presbyterorum ordinis, nn. 17, 20 y. 21 . 
El consejo de asuntos económicos lo pueden formar laicos, incluso mujeres, que reúnan las condiciones requeridas, como es la de que sean de probada integridad y expertos en materias económicas y civiles. Su duración ha de ser por un período de cinco años y se excluyen los parientes del obispo diocesano hasta el cuarto grado de consanguinidad o afinidad (c. $492 \S \S 2-3$ ).

Esta materia se rige por el Libro V sobre los bienes temporales bajo las indicaciones del obispo diocesano, según el presupuesto anual, para que no haya desconexión con el Ordinario. Hay que tener en cuenta la legislación de la Conferencia Episcopal, como el límite mínimo y máximo a efectos del c. 1292, que en España son cinco y cincuenta millones de pesetas ${ }^{60}$. Hay un consejo nacional de economía.

El consejo de asuntos económicos asume las anteriores funciones de la sección de bienes, clero y culto, Seguridad Social, etc. Forma una sección separada y con cierta autonomía dentro de la curia diocesana. El ecónomo ha de administrar los bienes de la diócesis siguiendo las directrices y orientaciones del consejo de asuntos económicos y del obispo diocesano. Esto conlleva la realización de actos de gestión por parte del ecónomo, que al final de cada año debe rendir cuentas ante el consejo de asuntos económicos (c. 494 § 4). El obispo diocesano le puede encomendar al ecónomo la administración de los patrimonios eclesiásticos, que no tengan administrador propio dentro de la diócesis. Le corresponde gestionar la Seguridad Social, la masa común diocesana y el instituto especial para la sustentación del clero según el c. 1274 $\S \S 1-3$. El fondo común diocesano debe tener un concepto unitario según los fines y respetando los derechos adquiridos. En algunas diócesis existe la caja de compensación, el acervo de pías fundaciones, fondo de reservas, etc. Se ha creado fondo común en 40 diócesis ${ }^{61}$.

\section{b) Consejo parroquial de economía y supraparroquial o arciprestal}

Según el c. 537, «en toda parroquia debe haber un consejo de asuntos económicos que se rige, además de por el Derecho universal, por las normas que haya establecido el obispo diocesano, y en el cual los fieles, elegidos según esas normas, prestan su ayuda al párroco en la administración de los bienes de la parroquia, sin perjuicio de lo que prescribe el c. $532 »$. La representación le corresponde al párroco en los negocios jurídicos y su administración de acuerdo con los cc. 1281-1282.

60. Cf. Decreto general de la Conferencia Episcopal Española, art. 14, que hemos visto anteriormente, Boletín 3 (1984) 103; y 5 (1985) 19-26, donde aparece el Reglamento de la Ordenación económica de la Conferencia, fondo común interdiocesano y su distribución en 1985 con presupuesto.

61. Se han creado fondos comunes por decreto. Cuando se publique la ponencia se podrán ver muchos detalles relevantes sobre esta materia. 
Las parroquias tienen su personalidad jurídica, reconocida en España por los Acuerdos de 1979. Lamentablemente, en algunas diócesis, los bienes parroquiales se están registrando a nombre de la personalidad jurídica de la diócesis por razones de técnica administrativa.

Un antecedente del consejo de economía o de asuntos económicos parroquiales está en las juntas parroquiales, que han velado por la defensa de los bienes parroquiales, reparación de la fábrica de la iglesia, casa cural, etc. Hay que tener en cuenta la diversidad de las regiones e incluso de parroquias aisladas con sus tradiciones peculiares.

En algunas diócesis se han creado consejos arciprestales de economía para atender a los auxilios materiales de los párrocos según c. 555 § 3. En otras diócesis se manda oír al arcipreste para que controle a los consejos de economía de su arciprestazgo. Se procura a veces evitar la burocracia con la centralización diocesana y arciprestal.

\section{c) Cuestiones canónicas implicadas con los consejos económicos}

Además de los fondos comunes, de los que ya se ha hablado, están el acervo o patrimonio artístico, la información a los fieles, el depósito general diocesano, etc. En España habrá que tener en cuenta, además de la legislación canónica, la Ley del patrimonio artístico del Estado y los Acuerdos de 197962.

Se ha avanzado mucho en el consejo diocesano de asuntos económicos y poco en lo parroquial, que es fundamental junto con los fondos comunes diocesanos. El juicio sobre los informes aportados es serenamente positivo en España, donde la Seguridad Social y jubilación se rigen por la legislación civil y normas de la Conferencia Episcopal.

Se va camino de una caja de compensación y comunicación de bienes, que ya se ha puesto en marcha con presupuestos y contabilidad técnicamente llevada para poder decir en qué se gasta, quién lo da y cómo se administra el dinero de la Iglesia.

\section{Asociaciones públicas y privadas de fieles}

Se parte de la sociabilidad humana, porque existe en los hombres una tendencia natural e innata al corporativismo civil o religioso. El derecho de asociación es algo fundamental.

Durante la Edad Media estuvieron los gremios con mucha pujanza y al lado de las Órdenes religiosas, surgieron las Órdenes terceras, las segundas, Co-

62. Hay acuerdos especiales en algunas comunidades autónomas, como Cataluña, Castilla y. León, etc. Otros están en elaboración. Cf. D. IguACEN Borau, La Iglesia y su patrimonio cultural (Madrid, EDICE, 1984) 249-269, donde puede verse la legislación vigente en 1984. 
fradías, Pías uniones, etc. Sobre el derecho de asociación hay declaraciones políticas, como la Declaración universal de los derechos humanos el 10 de diciembre de 1948, que tiene sus antecedentes y confirmaciones posteriores, como las del Concilio Vaticano II ${ }^{63}$.

En el Código de 1917 se habla de asociaciones religiosas y nó religiosas. Lás religiosas podían ser laicales o eclesiásticas, erigidas; aprobadas o recomendadas. Estaban también lás obras pías o fundaciones. Se reconocía el derecho de ásociación de los fieles en el c. 684 del Código de 1917, que era bastante parco en esta materia, al silenciarse las asociaciones privadas, cuya personalidad jurídica quedaba en tela de juicio. Ya en 1920 se presentö el caso de la Congregación de San Vicente de Paúl «in câsu corrientense con el obispo de Corrientes ${ }^{64}$.

Posteriormente se presentó el caso de la Acción Cátólica y luego el del Opus Dei, que llegó a catologarse - como Pía unión-, surgiendo los Institutos seculares en 1947, sin que se diese una solución satisfactoria, por lo que se proponían diversas sugerencias antes de la reforma del Código ${ }^{65}$.

\section{a) Normativa del Código de:1983}

De acuerdo con la doctrina del Concilio Vaticano II se da una mejor ubicación, en el título V, de la primera parte del Libro II, Del pueblo de Dios (cc. 298-329). Se trata precisamente del desarrollo normativo y necesario del c. 215 , donde se establece el derecho de asociación de los fieles. Hay que tener en cuenta también los presupuestos lógico-normativos de la persona jurídica (cc. 114-123).

Se reconoce, junto con el derecho de los fieles en general, el derecho y deber de los laicos, de los clérigos y de los religiosos a asociarse, aunque la Iglesia modera a veces esos derechos y deberes al pedir a los clérigos que se abstengan de constituir o participar en asociaciones, cuya finalidad y actuación seàn incompatibles con las obligaciones propias del estado clerical, sean obstáculo o desdigan (c. $278 \S 3$ ). Algunas son inconciliables y por tanto prohibidas.

- Hay normas comunes a todas las asociaciones (cc. 298-311).

- Normas propias de las asociaciones públicas de fieles (cc. 312-320).

- Normas de las asociaciones privadas de fieles (cc. 321-329).

63. Gaudium et spes, nn. 9 y 68; Christus Dominus, nn. 16 y 17; Apostolicam actuositatem, nn. 16, 19 y 24; Dignitatis humanae, n. 4, etc.

04. Sagrada Congregación Del Concilio, Decreto del 13 de noviembre de 1920, AAS, 13 (1921) 135-144.

65. A. Alonso Lobo, «Perspectivas de una futura revisión del Código de Derecho Canónico», Comentarios al Código de Derecho Canónico, 2 (Madrid, BAC, 1963) 55-57. 
Dentro de las normas comunes está su naturaleza jurídica, que es la peculiar de los fieles, distintas de las asociaciones de los Institutos de vida consagrada y de las Sociedades de vida apostólica (c. 298). Se trata de sus elementos esenciales, como los miembros, fines, medios, intervención de la autoridad eclesiástica, estatutos, forma de constituirse, etc.

\section{b) Régimen de las asociaciones públicas}

Son públicas las asociaciones, que están erigidas por la autoridad competente: si es universal, por la Santa Sede; nacional, por la Conferencia Episcopal; diocesana, por el obispo diocesano (c. $312 \S 1$ ). No puede ser erigida por el Administrador apostólico. Algunos Institutos religiosos tienen privilegio especial (c. $312 \S 2$ ). Sus estatutos deben estar aprobados (c. 304) y necesitan incluso de nueva aprobación si se hacen correcciones o revisiones. Pueden tener normas internas (c. 209).

Las asociaciones públicas actúan en nombre de la Iglesia y sus bienes son eclesiásticos, por lo que hay mayor control sobre ellas con rendición de cuentas anual (cc. 319 y $1357 \S 1$ ). Tienen personalidad jurídica.

Se pueden suprimir por la autoridad eclesiástica competente, que las erigió o de la que dependan. Incluso el obispo diocesano puede suprimir a las de religiosos por causas graves; pero debe oír antes a su presidente y demás oficiales mayores (c. $320 \S \S 1-2$ ).

Se puede constituir también una asociación o confederación de asociaciones públicas, como persona jurídica pública (c. 313).

c) Régimen de las asociaciones privadas

Está aquí la mayor innovación del Código de 1983 sobre asociaciones. Hay asociaciones privadas sin personalidad jurídica, en las cuales los fieles miembros las dirigen y administran libremente con su presidente, oficiales y estatutos (c. 324 \& 1). Sus bienes no son eclesiásticos y están solamente sometidas a una vigilancia general de la autoridad competente eclesiástica según (cc. $305,323 \S 1$ y $1257 \S 2$ ).

Sus estatutos necesitan ciertas aprobaciones y pueden ser alabadas, remendadas o reconocidas por la autoridad eclesiástica, que aprueba sus estatutos (c. $299 \S \S 2-3$ ). Se les puede suprimir según estatutos o por la autoridad competente (c. $326 \S 1$ ). Tienen su asesor espiritual (c. $324 \S 2$ ) al que pueden escoger libremente; pero necesita confirmación del Órdinario del lugar.

La misma asociación privada puede adquirir personalidad jurídica al constituirse por decreto formal (c. 322) de la autoridad competente según c. 312. Sus estatutos deben estar aprobados (c. $322 \S 2$ ). Son suprimibles según estatutos y por la autoridad competente, como las anteriores (c. $326 \S 1$ ), si su actividad es un daño grave de la doctrina o de la disciplina eclesiástica, o causa 
escándalo a los fieles. Sus bienes no son eclesiásticos y su autonomía es amplia con limitaciones (c. 310) ${ }^{66}$.

\section{DERECHO LITÚRGICO-DIOCESANO, PASTORAL Y SACRAMENTAL}

Se recogen en esta sección dos ponencias de las VI Jornadas Informativas sobre temas sacramentales, una del profesor de la Universidad Pontificia de Salamanca, Federico R. Aznar Gil, desarrollada el día 12 de abril, a las 7 de la tarde, y otra del P. José María Díaz Moreno, S.J., que la expuso el día 13 a las 10 de la mañana. Guardan cierta relación al complementar lo referente a los sacramentos en el Derecho particular.

\section{La preparación jurídico-pastoral para la celebración del matrimonio}

Sobre esta materia ha publicado bastante Federico R. Aznar Gil, que se limitó a recapitular sus trabajos con algunos anexos nuevos sobre Documentos Diocesanos Españoles prematrimoniales (1976-1985) ${ }^{67}$.

Una de las quejas, que más se oían sobre el Código de 1917, era la escasa atención pastoral, que se prestaba a los futuros esposos en los cc. 1018-1034, ya que todo se reducía a que, antes de la celebración del matrimonio, constase que nada se oponía a la válida y lícita celebración del matrimonio según el c. 1019 del mismo Código de 1917.

Uno de los cambios, según el profesor Aznar Gil, más profundos y significativos, que se han producido en el nuevo Derecho matrimonial, es el capítulo relativo a la preparación para el matrimonio (cc. 1063-1072) distinguiendo lo pastoral de lo jurídico, sin separarlo, con una actuación fundamental unitaria de acuerdo con la Eclesiología del Concilio Vaticano II, que insistió en la importancia de esta preparación.

Se trata, como lo está haciendo la legislación prematrimonial española, de un intento pastoral-canónico para responder a las nuevas exigencias humanas y cristianas, que presenta el matrimonio.

66. Sobre su reconocimiento civil y funcionamiento en España ver J.M. DE PRADA, «Personalidad civil de los entes eclesiásticos» y «Actividades benéficas y asistenciales de la Iglesia», Los Acuerdos entre la Iglesia y España (Madrid, BAC, 1980) 221-290. La fundación no autónoma no puede adscribirse a una asociación privada. Para el registro civil se necesita: $10^{\circ}$ autenticación canónica ante notario; $2 .^{\circ}$ Estatutos aprobados y autenticados y $3 .^{\circ}$ certificado de fines religiosos o culturales. A veces se exige inventario de bienes.

67. F.R. AzNAR GIL, «Preparación para el matrimonio», Nuevo Derecho matrimonial canónico (Salamaca, Universidád Pontificia, 1983) 113-134; . $^{\mathrm{a}}$ edic., pp. 178-180. 


\section{a) La nueva legislación eclesiástica y su contenido}

Se recoge en el Código de 1983, además de las orientaciones del Concilio Vaticano II, la aportación del Sínodo de obispos de 1980 y de la exhortación apostólica Familiaris consortio de Juan Pablo II del 22 de noviembre de 1981. Ya se había adelantado mucho en esta materia con el Ritual del Matrimonio, que se fue acomodando a partir de 1970 a las distintas lenguas, naciones y exigencias humano-cristianas.

El c. 1063, que abre esta sección del Código de 1983, es ambicioso en su contenido y alcance, mezclando normas jurídicas y lenguaje catequético para señalar el objetivo, las responsabilidades y el ámbito de la preparación. Esta atención recae principalmente sobre los que van a contraer matrimonio, pero se extiende a todos los cristianos, especialmente a los que ya lo han contraído. Hay una preparación personal remota, que comienza en la infancia, y otra próxima y más específica. Sigue una preparación inmediata a la celebración litúrgica. Esta última debe tener lugar en los últimos meses o semanas que preceden al matrimonio. La regularización de esta preparación hoy corresponde al Ordinario del lugar, que puede recurrir, si le parece conveniente, a hombres y mujeres con experiencia y competencia (c. 1064). Luego debe seguir la ayuda permanente. Hay mucha y buena legislación diocesana.

b) Pluralidad de situaciones de los contrayentes

Además de la revalorización de la fe personal en la preparación para la celebración correcta del matrimonio, ya que su falta compromete a la validez, hay que atender a los menores de edad (cc. $1071 \S 1 \mathrm{nn} .2$ y $6 ; 1072$ y $1083 \S 2$ ). En España se está procurando armonizar lo canónico con lo civil, aunque no siempre es posible, ya que hay diferencias en la edad para la celebración. El c. $1083 \S 1$ exige para la validez 16 años en el varón y 14 en la mujer, mientras que el Código civil español exige la mayoría de edad a los 18 años (art. 315) o la emancipación (art. 46); pero se requieren 16 años cumplidos y que la consienta (art. 317). Por eso la Conferencia Episcopal establece que «no podrán contraer lícitamente el matrimonio el varón y la mujer que no hayan cumplido 18 años» ${ }^{68}$. Es un impedimento impediente en España para el matrimonio canónico.

Se presentan casos de uniones irregulares, como uniones libres y matrimonio civil sin dispensa (c. $1071 \S 1$, n. 3). No creyentes y no practicantes (c. $1071 \S 1$, n. 4). Esto es lo más frecuente y problemático. Hay diversos crite-

68. Conferencia Episcopal Española, Decreto general, art. 11, Boletín, 3 (1984) 103. Sobre facultades de los obispos diocesanos y Ordinarios del lugar en el matrimonio. Cf. A. MolinA, «La potestad de los Obispos», pp. 12-14. Esto lo veremos posteriormente mejor. 
rios de solución. Casos de matrimonios mixtos (cc. 1124-1129) sobre los que hay normas y orientaciones del Episcopado español. Se dan otras situaciones difíciles o irregulares de quienes se declaran católicos «muy alejados» y quieren casarse canónicamente. Por eso hay diferentes disposiciones sobre la celebración de estos matrimonios.

Hay casos de personas que han abandonado la fe de un modo formal y notorio. Otros no quieren seguir la forma canónica. Sobre esto se trata en el Directorio de Sevilla, posterior al Código de $1983 .{ }^{69}$.

\section{c) Conclusiones a las que se llegó en el coloquio}

Después de examinar 61 documentos diocesanos españoles sobre el matrimonio, se llegó a la conclusión de que las orientaciones son positivas. Conviene que algunos de estos documentos se pongan al día de acuerdo con el Código de 1983.

Los párrocos han de proceder en esta materia con cautela y precaución, como en el caso de los menores. A ellos les toca juzgar sobre la oposición razonable o no de los padres. Conviene que acudan al Ordinario del lugar, al que le toca decidir y aplicar las normas con las acomodaciones oportunas, respetando la legislación civil. Son frecuentes los casos de no practicantes o de quienes viven en situación de agnosticismo o ateísmo práctico, otros han caído en censuras, etc. (c. $1071 \S 1$, nn. 4-5). Excepto en caso de necesidad, nadie debe asistir sin licencia del Ordinario del lugar. De ahí la importancia de la legislación particular.

\section{El Derecho «litúrgico» diocesano pos-codicial}

El título de esta ponencia fue clarificado por José M. ${ }^{a}$ Díaz Moreno, profesor de Derecho Canónico en ICADE y Universidad de Comillas (Madrid). El tema es muy amplio y lo dividió en dos partes. En la primera se recoge una enumeración de remisiones, directas o indirectas, a los derechos particulares en relación a los sacramentos (excepto el del matrimonio canónico) por haber sido tratado antes, actos de culto, lugares y tiempos sagrados. Esto es lo que se comprende bajo la titulación general e imprecisa de «Derecho litúrgico» y se va a reproducir aquí.

En la segunda parte se ofreció una visión panorámica sólo aproximativa sobre el Derecho particular diocesano en España y que ha sido promulgado después de la entrada en vigor del Código de 1983. Ésta se omite ya que a cada uno le interesa principalmente lo de su diócesis. Además es una legislación aún

69. «Directorio pastoral sacramental. Sacramento del matrimonio», 1 de enero de 1985, Boletín oficial del Arzobispado de Sevilla, 126 (1985) 39, 94-122. 
in fieri y poca la desarrollada. Lo recogido puede servir de orientación a otras diócesis.

Según el c. 2 del Código de 1983, ordinariamente éste «no determina los ritos que han de observarse en la celebración de las acciones litúrgicas; por lo tanto, las leyes litúrgicas vigentes hasta ahora conservan su fuerza, salvo cuando alguna de ellas sea contraria a los cánones del Código». Una cósa es la celebración canónica y otra la litúrgica. La primera incide en la segunda a veces y viceversa.

Algunos religiosos por desconocimiento y otros, por no haberse puesto al día en esta materia o por descuido más que désprecio, no cumplen las normas del Código de 1983, ni las de la Iglesia particular, que les obligan, por lo que los Presidentes de la CONFER masculina y femenina han enviado una carta dando aclaraciones a la Comisión Episcopal de Liturgia en España ${ }^{70}$. Se publica lo siguiente a fin de colaborar en la información.

\section{A) Remisiones legales sóbre los sacramentos}

Cánones introductorios sobre la función santificadora de la Iglesia (cc. 838-848). Interesan también los cc. 834-837.

a) Competencia de los obispos diocesanos en la «ordenación» de la Liturgia (c. $838, \S \S 1$ y 4): se afirma su competencia subordinada y acumulativa con la S. Sede. En consecuencia, en la Iglesia particular confiada al Obispo y, dentro de los límites de su competencia, le corresponde promulgar «normas obligatorias» para todos «en materia de Liturgia». En este canon se establece una distinción entre la competencia para la «ordenación», es decir, para la promulgación legítima de leyes o decretos diocesanos sobre Liturgia y la competencia ciertamente más amplia, para urgir la observancia de las leyes litúrgicas universales. Aspecto este último que entraría dentro del ámbito específico de la potestad ejecutiva o administrativa (cfr. cc. 135-139).

b) Obligación de los Ordinarios locales de cuidar que «las oracionès y prácticas piadosas y sagradas», se ajusten a las normas de la Iglesia (c. 839 $\S 2$ ). Los Ordinarios del lugar son los principales custodios de la vida litúrgica en la Iglesia particular a ellos encomendada.

-Se trata de un derecho-deber a una vigilancia pastoral, que va más allá de la estricta ortodoxia dogmática, moral o canónica. Su finalidad es evitar la anarquía y subjetivismos, que vulneran a la Liturgia.

70. Comisión Episcopal de Liturgia, «Carta a los Superiores de Órdenes, Congregaciones religiosas», del 2 de diciembre de 1984, Boletín de la Conferencia, 5 (1985) 36-37; I. IGLESIAS y B. García, «Carta al Presidente de la Comisión Episcopal de Liturgia», Vida Nueva del 20 de abril de 1985, n. $^{\circ} 1275$ (1985) 21 : 
c) Corresponde al obispo diocesano establecer una normativa adecuada para la lícita celebración, administración y recepción de los sacramentos «así como también el Ritual, que debe observarse en la celebración» respetando las competencias de la Santa Sede y Conferencia Episcopal (cc. 838 \& y 841).

- Se reserva a la Santa Sede todo lo referente a la validez de los sacramentos (c. 841), la edición de los libros litúrgico-sacramentales (c. 838 \& 2) el reconocimiento de sus versiones en las lenguas vernáculas (ibid.) y velar por el cumplimiento de las normas litúrgico-canónicas a nivel universal. A los obispos diocesanos les compete lo referente a licitud dentro del ámbito de su potestad (cc. $338 \S \S 3-4$ y 841). Anteriormente vimos las competencias de la Conferenca Episcopal.

d) Compete al obispo diocesano y Conferencia Episcopal determinar en qué casos de necesidad grave, además de «peligro de muerte», se puede administrar los sacramentos de la penitencia, Eucaristía y unción de los enfermos a los «demás cristianos, que no están en plena comunión con la Iglesia católica», supuestas las condiciones expresadas en este texto legal (c. $844 \S 4$ ). Sobre la normativa ecuménica hay disposiciones en algunas diócesis, como la de Málaga, sobre entierros de no-católicos ${ }^{71}$.

e) Conexa con esta materia está la referente a las ofrendas de los fieles con ocasión de la administración de sacramentos (c. 848). Se trata de un principio fundamental, que debería tenerse en cuenta sobre los estipendios por la aplicación de misas (cc. 951, $952 \S \S 1-2,956,957$ y 958). Esto se verá mejor al tratar de la Eucaristía.

- Sobre esta competencia de los obispos en el c. 848 hay dos normas explicitativas: $1 .^{a}$ la prohibición expresa de pedir nada «fuera de las ofrendas determinadas por la autoridad competente», y $2 .^{\text {a }}$ se señala implícitamente la competencia de la autoridad episcopal, el concilio provincial o los obispos de la provincia eclesiástica para fijar lo relativo a las ofrendas.

-Las competencias de la Conferencia Episcopal, como ya hemos visto, son muy importantes, lo que está dando origen a un Derecho particular, que procurará salvar la unidad y uniformidad litúrgico-canónica en las diferentes naciones o en territorios extensos.

- Tanto cuantitativa, como cualitativamente, hay diferencias entre las facultades de obispos diocesanos y los Ordinarios del lugar, lo que habrá de tenerse en cuenta, aunque a veces se confunden (c. 134).

\section{El bautismo}

a) Los Ordinarios del lugar pueden «permitir o mandar» que haya pila

71. Directorio de Pastoral funeraria (Málaga, 1 de abril de 1982) 133. 
bautismal en otras iglesias u oratorios dentro de los límites parroquiales (c. $858 \S 2$ ).

- Se exige la verificación de dos condiciones, que no afectan a la validez de la posible disposición del Ordinario: $1 .^{\mathrm{a}}$ que se oiga al párroco y $2 .^{\mathrm{a}}$ que sea para «comodidad» de los fieles.

b) La administración del bautismo en casas particulares, puede ser permitida por el Ordinario del lugar, existiendo causa grave y «otras causas» lo mismo que en «clínicas y hospitales», si así lo dispone el obispo diocesano o lo exige una razón pastoral (c. $860 \$ \S 1-2$ ).

-La razón pastoral puede quedar fijada, al menos ejemplificativamente, por el Derecho diocesano, atendiendo a las circunstancias de lugares, personas, tiempos, etc. Se da una gradación entre las causas establecidas para la administración en casas particulares (con permiso del Ordinario del lugar y causa grave, salvo caso de necesidad) y en las clínicas o en hospitales (lo que puede disponer el obispo diocesano o aunque no exista esta disposición, si viene exigido por una «razón pastoral»).

c) Designación de un catequista u otra persona por el Ordinario del lugar para la administración lícita del bautismo «si está ausente o impedido el ministro ordinario» (c. $861 \S 2$ ).

-Esta designación puede hacerse mediante una norma de carácter general, si así lo aconsejan las circunstancias. Según J.M. Díaz Moreno, el Ordinario local puede delegar en el párroco para que sea éste quien designe. Esta delegación también podría revestir el carácter de una norma general. Otros opinan que sería de carácter particular.

d) Es competencia del obispo diocesano el establecer una edad diferente de la determinada en el Derecho común o general (16 años) para ser padrino del bautismo (c. $874 \S 1,2 .^{\circ}$ ).

- La determinación de esa edad diferente puede ser mayor o menor que la establecida en el Código de 1983, según lo aconsejen razones pastorales, por permisión del mismo Código.

e) Los obispos diocesanos son ministros ordinarios del bautismo (c. 861 $\S 1$ ) especialmente de los adultos, por lo que deben ofrecerse a bautizar a los que han cumplido 14 años, para administrarles el bautismo (c. 863). Se le debe notificar al obispo diocesano para que él disponga lo que crea más conveniente.

\section{La confirmación}

a) Corresponde a los obispos diocesanos o no, la consagración del santo crisma, que se debe emplear en la confirmación (c. $880 \S \S 1-2$ ). 
-Son los ministros ordinarios, aunque pueden administrarlo por sí o por otro obispo (cc. 882 y 884). Están obligados a administrarlo (c. 885).

b) El presbítero dotado de facultad por el Derecho común o por concesión de la autoridad competente (c. 882). Esta concesión peculiar puede ser una designación por parte del obispo, que puede delegar su facultad ordinaria $\mathrm{u}$ originaria en uno o varios sacerdotes (cc. $883,2 .^{\circ}$ y $884 \S 1$ ).

-J.M. ${ }^{a}$ Díaz Moreno opina que la "peculiaridad de la concesión no equivale a la necesidad de una concesión "singular a una persona determinada», ya que eso no lo exige el canon, sino que más bien lo peculiar aquí se contrapone a la facultad concedida por el Derecho general. Esto no impide que esa «designación peculiar» pueda hacerla el obispo diocesano mediante un decreto, dentro de un adecuado nivel de generalidad.

c) Posibilidad de una prohibición expresa por parte del Ordinario propio para que sus súbditos reciban la confirmación de manos de un obispo, que no sea su Órdinario, aunque éste administre la confirmación en su propio territorio (cc. $866 \S 1$ y 887 ).

- Se establece aquí una lógica prevalencia de lo personal sobre lo territorial: La prohibición «expresa» puede establecerse por el Ordinario propio mediante decreto. Se exceptúa el caso de peligro de muerte (cc. 886 \& 1 y 883 , $\left.3 .^{\circ}\right)$.

d) La edad adecuada para recibir la confirmación puede quedar a la determinación de la Conferencia Episcopal (c. 891). En el Decreto general de la Conferencia Episcopal Española, art. 10, se establece como edad adecuada «en torno a los 14 años», pero queda a salvo, como ya hemos visto, «el derecho del obispo diocesano a seguir la edad de la discreción» a la que hace referencia el canon.

-Si no existe una normativa particular diocesana, se presume que se acepta la edad señalada por la Conferencia Episcopal. Nada impide, sin embargo, que por normas diocesanas se ratifique expresamente esa presunción.

e) Libro de confirmaciones, que puede ser establecido por la Conferencia Episcopal u obispo diocesano, en cada parroquia, además del Libro de confirmáciones de la curia diocesana (c. 895).

- Por medio de una normativa diocesana, el obispo puede completar esta disposición, estableciendo v.gr. que se comuniquen las confirmaciones a la curia diocesana en orden a un registro central diocesano de las mismas, lo cual es indudable que facilitaría mucho la búsqueda de los testimonios o partidas de confirmación. 


\section{Eucaristía}

- Los Ordinarios están facultados para entregar la carta comendaticia a los sacerdotes para que puedan ser admitidos a celebrar la santa misa (c. 903). Entre los Ordinarios se incluye a los Superiores Mayores.

a) Facultad para binar o trinar. Ante la escasez de sacerdotes, los Ordinarios del lugar pueden conceder con causa justa la facultad de binar en los días feriales y de trinar los domingos y días de precepto, si lo exige una «necesidad pastoral» (c. $905 \S 2$ ).

- Conviene notar la diferencia entre las causas exigidas para la binación y para la trinación o celebración de tres misas, la cual no parece pueda concederse fuera de los días festivos. El obispo diocesano puede completar esta legislación explicando lo que se entiende en el ámbito diocesano por «causa justa» para la binación y por «necesidad pastoral» para la trinación.

- Sorprende a veces oír que algunos sacerdotes celebran más de tres misas. ¿Puede conceder el Ordinario del lugar facultad para celebrar cuatro misas? ¿Puede prohibirlo? J.M. ${ }^{a}$ Díaz Moreno entiende que puede prohibirlo. De hecho así se ha establecido en alguna diócesis, como demostró en la segunda parte de su trabajo ${ }^{72}$. A veces debería prohibirse.

b) Designación del ministro extraordinario para la comunión a tenor de los cc. $230 \S 3$ y $910 \S 2$. Aunque no se exige expresamente la licencia del obispo diocesano, ni del Ordinario del lugar, en el c. 910 , se necesita en la práctica por sus antecedentes jurídico-canónicos.

-Esta designación puede ser habitual por parte del Ordinario del lugar «ad actum vel ad casum» o incluso, si fuese verdaderamente necesario, de modo estable. Puede delegarse en el párroco o en el Director de un colegio, etc. Debería hacerse mediante una adecuada normativa de ámbito diocesano.

c) El Ordinario del lugar puede permitir a un sacerdote enfermo o incapacitado para que celebre misa sentado en el templo «con asistencia de fieles» (c. $930 \S 2$ ).

- La licencia del Ordinario del lugar es para la asistencia de fieles, ya que el sacerdote incapacitado tiene esa facultad por el mismo Derecho para celebrarla en privado. Se trata de algo individual o personal.

d) Licencia expresa del Ordinario local para celebrar en un templo nocatólico (c. 933) con justa causa y evitando el escándalo.

-Debe notarse que, a tenor de la ley y de sus fuentes legales, no bastaría la

72. Esto se podrá ver mejor cuando se publique la ponencia completa, ya que la segunda parte contiene la «panorámica del Derecho particular diocesano» con las determinaciones de cada obispo diocesano. 
licencia implícita. Según J.M. ${ }^{a}$ Díaz Moreno en determinadas circunstancias esa licencia expresa puede presumirse.

e) Licencia para reservar el Santísimo en iglesias, oratorios y capillas (c. $934 \S 1,2 .^{\circ}$ ) por parte del Ordinario del lugar.

- Hay que tener en cuenta lo que se prescribe en el mismo c. 934 § 2 sobre la exigencia de que haya alguien - no necesariamente un sacerdote- que se responsabilice o tenga cuidado y que «en la medida de lo posible se celebre allí la Misa al menos dos veces al mes».

f) Normas del obispo diocesano para que el sacerdote lleve consigo la Eucaristía o para tenerla en casas particulares (c. 935).

- Para conceder esta licencia, de forma particular o general, ya que el Código no distingue, se exige «una razón pastoral». Al no especificarse como «grave», admite una interpretación amplia, aunque, dada la materia de que se trata, deberá evitarse cualquier género de abuso.

-Se necesita permiso del Ordinario del lugar para reservar la Eucaristía en otro oratorio, además de la iglesia u oratorio principal de una casa religiosa o «piadosa» con justa causa (c. 936). Se puede dar esta licencia en forma general con las condiciones señaladas en c. $934 \S 2$.

g) Exposición y reserva del Santísimo por una persona, que no sea sacerdote ni diácono. Puede conceder esta licencia el obispo diocesano; pero se excluye la bendición (c. 943).

-Como "circunstancia peculiar» puede entenderse la ausencia o presencia difícil de un sacerdote o diácono. Si es posible se debe seguir el orden de preferencia establecido en el mismo canon: $1 .^{\circ}$ el acólito; $2 .^{\circ}$ el ministro extraordinario de la comunión y $3 .^{\circ}$ otra persona encargada por el Ordinario del lugar, observando las prescripciones dictadas por el obispo diocesano. Esta designación o encargo puede hacerse en forma de decreto o mediante normas especiales.

h) Normas sobre procesiones, especialmente con el Santísimo (c. 944 $\S 1$ ). Corresponde al obispo diocesano dictar las normas para organizar procesiones por calles públicas, especialmente el día del Corpus Christi sobre su oportunidad y modo de la manifestación del culto público.

. -Dentro de estas facultades, que comprenden la exigencia de la participación de los fieles y su decoro (c. $944 \S 2$ ), se puede urgir la asistencia de los sacerdotes a la procesión del Corpus, como los miembros del cabildo o párrocos residentes en la ciudad. Sin embargo se da una gran mitigación si se compara con el derogado c. 1291 del Código de 1917 sobre esta materia.

i) Determinación del Ordinario del lugar sobre estipendios de binaciones (c. 951). Esta determinación puede hacerse mediante decreto. Salvo que así lo 
disponga algún decreto diocesano, el sacerdote puede retener, aún en las misas binadas, lo que propiamente no es estipendio, sino que se da por el título extrínseco de desplazamiento molestia, etc. ${ }^{73}$.

-Ya se dijo anteriormente que es competencia del Concilio provincial o de la reunión de los obispos de la provincia eclesiástica la fijación del estipendio de misas y aranceles (c. $952 \S 1$ ). Para la reducción de misas fundadas hay que tener en cuenta lo que prescribe el c. 1308. Es lógica una periódica actualización de los estipendios dados los cambios de la moneda y de la vida con su coste, aunque, claro está, la sustentación del sacerdote no puede establecerse, ni fundarse en los estipendios de misas.

-Corresponde a los Ordinarios determinar el modo, según el cual, quienes están obligados a la celebración de misas, deben enviar a la curia diocesana las cargas de las que no hayan podido celebrarse durante el año (c. 956). El año se cuenta a tenor del c. $202 \S 1$. Si se trata de fundaciones, el año se cuenta del 1 de enero al 31 de diciembre ${ }^{74}$.

-Corresponde al Ordinario local, en relación con las iglesias del clero secular, la vigilancia del cumplimiento fiel de las cargas de misas c. 957). Lo mismo compete a los superiores para las iglesias de Institutos religiosos o Sociedades de vida apostólica (ibid.). Esto puede hacerse mediante una normativa de tipo general o especial.

-Sobre la revisión anual de los libros de encargo de misas (c. 958 §). El Ordinario tiene obligación de revisar cada año esos libros personalmente o por medio de otro. Y quiénes sean estas personas pueden designarse por decreto.

\section{Penitencia}

Sobre esta materia tiene J.M. ${ }^{a}$ Díaz Moreno un estudio especial ${ }^{75}$.

a) Sobre absolución general o tercer modo de reconciliación (c. $961 \S 2$ ). Corresponde al obispo diocesano, teniendo en cuenta los criterios de la Conferencia Episcopal, juzgar o señalar cuándo se dan los requisitos necesarios para que se imparta la absolución general en caso de «grave necesidad». El obispo

73. Hay que atenerse a lo establecido en cada diócesis sobre los aranceles y estipendios de misas, lo que se ha procurado poner al día desde 1983 a 1985. Según el c. $951 \S 1$, «el sacerdote que concelebra una segunda misa en el mismo día, no puede recibir por ella estipendio bajo ningún título». En esta materia evítese hasta la más pequeña apariencia de negociación (c. 947).

74. J. Manzanares, nota al c. 956 en el Código de Derecho Canónico (Madrid, BAC, 1983) 470. Se sigue lo que había dicho sobre esto D. Lorenzo Miguélez al comentar el c. 841 del Código de 1917 en la BAC.

75. J.M. ${ }^{a}$ DÍAZ MORENo, «Las innovaciones de la disciplina sobre el sacramento de la penitencia», en XVIII Semana Española de Derecho Canónico (Salamanca, Universidad Pontificia, 1984) 253-292. Es muy interesante y está bien documentado con resumen de las innovaciones al final. 
diocesano es el único competente para juzgar sobre esto en su diócesis, dentro de los criterios acordados por la Conferencia Episcopal, que puede o debe hacerlo mediante Decreto general. Esos criterios señalarán unas líneas de «máximos» y «mínimos», a un cierto nivel de generalidad.

-El obispo diocesano, atendiendo a la realidad concreta diocesana, deberá aplicar luego esos criterios mediante una adecuada normativa. De esto se sigue que el tercer modo de reconciliación tendrá siempre un carácter excepcional.

b) Facultad para oír confesiones (cc. 967-975)

-Los obispo tienen facultad para oír confesiones a los fieles en todo el mundo, a no ser que el obispo diocesano se opusiese en un caso concreto (c. $967 \S 1$ ).

- Los Ordinarios del lugar son competentes para otorgar facultad a cualquier sacerdote para confesar a cualesquiera fieles. Si es un miembro de un Instituto religioso, debe tener al menos licencia presunta de su Superior para usarla (c. $969 \S 1$ ).

-El Superior de un Instituto religioso o de una Sociedad de vida apostólica puede otorgar esa facultad a cualquier presbítero para oír las confesiones de sus súbditos y de aquellos otros, que moran día y noche en sus casas (c. $969 \S$ 2). El superior local sólo para su casa y a sus súbditos teniendo en cuenta lo establecido en el c. $968 \S 2$.

-En caso de un sacerdote extradiocesano, el Ordinario del lugar, no le concederá licencia para confesar, aunque tenga allí domicilio o cuasi domicilio, sin consultar previamente a su Ordinario (c. 971).

- No debe revocarse la facultad de oír confesiones sin causa grave y avisando al Ordinario o Superior competente. Sobre revocación ver c. 974.

-Acertadamente opina J.M. ${ }^{a}$ Díaz Moreno que, dada la reordenación de toda esta materia y la variación de criterios seguidos por el legislador en el nuevo Código, con relación al anterior, parece oportuno que - a nivel diocesano-, tal como se ha hecho en algunas diócesis, se decrete o precise quiénes obtienen esa facultad en virtud de su cargo y quiénes en razón de la incardinación o domicilio.

- Conviene observar que la facultad para oír confesiones por razón del oficio o concesión del Ordinario del lugar cesa no sólo por revocación, sino también por pérdida del oficio, excardinación o cambio de domicilio según el c. 975 .

- Si el Ordinario del lugar, que concedió las facultades para confesar, se las revoca, el presbítero queda privado de las mismas en todas partes (esto afecta también a los que las han adquirido por razón de la incardinación o domicilio a tenor del c. $967 \S 2$ ). Si revocadas por otro Ordinario del lugar, sólo las pierde en su jurisdicción territorial (c. $974 \S 2$ ). Algo semejante pasa con las licen- 
cias concedidas por el Superior Mayor propio, que puede revocar otro Superior competente o local dentro del ámbito de su potestad (c. 974 § 4).

7. Concesión de indulgencias (cc. $995 \S 1$ y 997)

Dentro de la parte de la penitencia hay un capítulo dedicado a las indulgencias, por lo que J.M. ${ }^{\text {a }}$ Díaz Moreno hizo una ligera referencia a ellas, recordando que, a tenor del Decreto de la Penitenciaría, In Constitutione Apostólica, del papa Pablo VI, del 29-VI-1968 ${ }^{76}$, los obispos diocesanos y asimilados, pueden conceder de jure, desde el comienzo de su oficio pastoral, indulgencia parcial a las personas o en los lugares que están bajo su jurisdicción. Esta facultad, que siguen teniendo los obispos, no obstante la desaparición del c. 914 del Código de 1917, puede darse por decreto.

\section{Unción de los enfermos}

-Corresponde al obispo diocesano y a quienes se equiparan a ellos en derecho la bendición del óleo (c. $999,1 .^{\circ}$ ). En caso de necesidad lo puede hacer cualquier presbítero, pero dentro de la celebración del sacramento (c. 999, 2. ${ }^{\circ}$ ).

- Los obispos diocesanos pueden dar normas para regular la celebración comunitaria del Sacramento de la Unción para varios enfermos al mismo tiempo (c. 1002).

-Dada la generalidad del texto legal, caben las más diversas modalidades de regulación según las circunstancias concretas de tiempos, lugares y personas. En el Ritual de la Unción y Pastoral de los Enfermos (nn. 71-76) se dan criterios muy oportunos, como orientación, que puede servir de base para la ordenación diocesana.

\section{Sacramento del orden}

Al exponer esta materia J.M. ${ }^{a}$ Díaz Moreno prescindió de los ministros de la sagrada ordenación y de otros requisitos por parte de los ordenandos (cc. 1012-1027).

a) El obispo diocesano tiene el derecho-deber de que los candidatos antes de recibir la ordenación, conozcan debidamente las obligaciones que lleva consigo (c. 1028).

-Teniendo en cuenta la naturaleza y la importancia de este derecho-deber, el obispo podría determinar el modo de dar a conocer estas obligaciones $\mathrm{v}$ el testimonio de que los interesados se dan por enterados de las mismas ${ }^{77}$.

76. AAS, 60 (1968) 414-419, n. 11, párrafo $1 .^{\circ}$.

77. Cf. Instructio Quam Ingens del 27-XII-1930, AAS, 23 (1931) 120-127. 
b) El obispo diocesano deberá determinar el tiempo durante el cual, el diácono deberá ejercer el orden recibido, antes de recibir el presbiterado (c. 1032 \& 2).

- No se señala tiempo alguno como límite máximo o mínimo. Como criterio orientador puede tenerse la disposición del c. $1035 \S 2$, que exige seis meses entre el acolitado y el diaconado.

c) Sobre los cinco días de ejercicios espirituales antes de la ordenación tienen competencia los Ordinarios en cuanto al modo de hacerlos (c. 1039).

-El obispo podría regular ese modo de forma general, ya que antes de proceder a la ordenación, debe ser informado sobre los ejercicios, es decir, si los han hecho debidamente.

-Se requiere un mínimo de cinco días. Algunos opinan que podría aumentarse hasta los ocho días. Dada la reorganización de esia materia, J.M. ${ }^{a}$ Díaz Moreno opina que han sido derogadas o no están en vigencia las disposiciones de la Sagrada Congregación de Sacramentos sobre esta materia ${ }^{78}$.

d) Pruebas a que debe ser sometido el neófito para recibir el orden (c. $1042,3 .^{\circ}$ ). Se considera un impedimento, a no ser que conste su aprobación.

- Se trata de algo que tiene rara aplicación entre nosotros. Si se multiplican los casos, podría el obispo diocesano promulgar las oportunas normas al respecto. Se entiende por neófito el que recibió el bautismo siendo ya adulto. Éste puede desear recibir el orden poco después.

e) Sobre lás investigaciones de las cualidades requeridas en los ordenandos puede el obispo diocesano determinar el modo de realizarlas (c. 1051, $2 .^{\circ}$ ). La idoneidad del ordenando ha de ser comprobada positivamente.

- Nada impide que puedan ser regulados esos «otros medios» mediante una normativa diocesana sobre testimoniales, informaciones, etc.

\section{El matrimonio}

Esta materia no fue desarrollada por J.M. ${ }^{a}$ Díaz Moreno, ya que había sido tratada anteriormente por F.R. Aznar Gil, quien se limitó a la preparación jurídico-pastoral para la celebración del matrimonio, como se ha visto anteriormente. Se marginaba gran parte de las facultades de los obispos y Ordinarios del lugar sobre el matrimonio. Para subsanar un poco esta laguna se intercala o añade lo siguiente:

a) Los Ordinarios del lugar pueden prohibir temporalmente el matrimonio a sus propios súbditos en cualquier parte y a los residentes en su territorio

78. AAS, 20 (1928) 359-380. 
(๔. 1077 § 1). Sólo la Santa Sede puede añadir a esta prohibición una cláusula dirimente (c. $1077 \S 2$ ).

- Sobre esta materia están los vetita judiciales y administrativos, que se regulan por los cc. 1077 y 1684 . Esto es distinto de los consejos o amonestación, como la prescrita en el c. 1072 para apartar a los jóvenes del matrimonio, cuando aún no han alcanzado la edad necesaria legal.

b) Los Ordinarios del lugar tienen facultades especiales en cuanto a la dispensa de impedimentos:

-En peligro de muerte, de todos los impedimentos de Derecho eclesiástico, tanto públicos como ocultos, reservados o no, excepto el impedimento del presbiterado (c. 1079 § 1). En las mismás circunstancias, pero sólo cuando, ni siquiera es posible acudir al Ordinario del lugar (o sólo puede hacerse por teléfono o telégrafo) tienen la misma facultad de dispensar el párroco, el ministro delegado, sacerdote o diácono asistente (c. 1079 § 2). El confesor sólo de los ocultos (c. 1079 \& 3).

- En caso perplejo o casos especiales los Ordinarios del lugar pueden dispensar de todos los impedimentos de Derecho eclesiástico a sus súbditos y a los que se hallan en su territorio, excepto los tres casos reservados a las Santa Sede: $1 .^{\circ}$ Órdenes sagradas, $2 .^{\circ}$ voto público y perpetuo de castidad en Instituto de Derecho pontificio y $3 .^{\circ}$ el crimen (c. $1080 \S 1$ ). Si se trata de casos ocultos, se exceptúa sólo el presbiterádo.

- Tanto el párroco como el sacerdote o diácono, a los que se ha mencionado anteriormente (c. $1079 \S 2$ ) han de comunicar inmediatamente al Ordinario del lugar las dispensas concedidas para el fuero externo, debiendo anotarse en el libro de matrimonio (c. 1081).

c) Los Ordinarios del lugar pueden autorizar el matrimonio condicionado (c. $1102 \S 3$ ) y contraerlo por procurador (cc. $1071 \S 1,7 .^{\circ}$ y $1105 \S 2$ ).

-Pueden dispensar de la forma canónica en peligro de muerte (c. $1079 \S 1$ ) y excepcionalmente en los matrimonios mixtos, cuando haya dificultades, siguiendo las normas establecidas por la Conferencia Episcopal (c. $1127 \S 2$ ).

- Pueden delegar la facultad de asistir al matrimonio a sacerdotes y diáconos. Esta facultad puede ser general (c. $1111 \S 1$ ). Donde no hay sacerdotes..., el obispo puede delegar en laicos a tenor del c. $1112 \S \S 1-2$.

-Pueden autorizar la celebración del matrimonio fuera de la parroquia de los contrayentes (c. 1115) o en una iglesia u oratorio distintos de la parroquia (c. $1118 \S 1$ ). Estas facultades las tienen también los párrocos. El Ordinario del lugar puede permitir la celebración del matrimonio en un lugar conveniente, como una casa particular (c. 1118 § 2).

-Autorizar la celebración de matrimonios mixtos en una iglesia o en otro 
lugar conveniente de una comunidad, que no está en plena comunión con la Iglesia católica de acuerdo con los cc. $1118 \S 3,1125$ y 1126.

-Pueden permitir el matrimonio secreto de acuerdo con los cc. 1130-1132.

-Mediante decreto pueden separar temporalmente a los esposos (c. 1153 $\S 1)$.

- Al cesar la causa de separación se ha de restablecer la convivencia (c. 1153 $\S 2$ ). Tienen otros derechos y obligaciones, que en parte han sido expuestos por F.R. Aznar en cuanto a la preparación, atención posterior, casos de matrimonios mixtos y otros problemáticos.

d) Los obispos diocesanos pueden autorizar, como se observó anteriormente, a un laico para que asista al matrimonio en lugares donde no hay sacerdotes, ni diáconos, previo el voto favorable de la Conferencia Episcopal y obtenida la licencia de la Santa Sede (c. 1112).

-Pueden dar normas, conjuntamente con la Conferencia Episcopal, sobre el modo de hacer la inscripción del matrimonio en los libros parroquiales (c. $1121 \S 1)$.

-Pueden conceder la sanación en raíz en casos concretos, aun cuando concurran varios motivos de nulidad, con excepción de los casos reservados a la Santa Sede, por estar reservada a ella la dispensa del impedimento o tratarse de un impedimento de derecho divino positivo o natural, que haya cesado (c. $1165 \S 2$ ) como la impotencia, ligamen, consaguinidad en línea recta, etc. Esta última no se dispensa. A veces se trata de casos dudosos. Hay otras facultades de los obispos diocesanos y de los Ordinarios del lugar sobre esta materia ${ }^{79}$.

\section{B) Remisiones canónicas-sacramentales y algunos actos de culto}

Los obispos diocesanos y Ordinarios del lugar tienen un papel importante en los actos del culto, además de los sacramentos, como son los sacramentales cuya definición aparece en el c. 1166.

a) Se requiere el juicio del Ordinario, para que, a tenor de lo establecido en los libros litúrgicos, los laicos puedan administrar ciertos sacramentales (c. 1168).

-Según observó J.M. ${ }^{a}$ Díaz Moreno, el texto del canon exige dos condiciones: $1 .^{a}$ que el Derecho litúrgico conceda a los laicos la administración de los sacramentales de que se trata; $2 .^{a}$ que a juicio del Ordinario sea procedente tal administración.

79. A. Molina, «La potestad de los obispos sobre los sacramentos», pp. 12-14. Hay varias erratas al citar los cánones. Cf. Normas de Conf. Epis. Esp. sobre matrimonios mixtos en Ecclesia del 13-II-1971, pp. 203-204. 
b) Exequias

-El Ordinario del lugar puede permitir las exequias de niños no-bautizados, que sus padres deseaban bautizar (c. $1183 \S 2$ ).

-Se recoge en este canon las disposiciones del Ritual de exequias ( $\mathrm{nn} .56 \mathrm{y}$ $62)$, cuyas orientaciones debe seguir el obispo diocesano al regular esta materia para impedir que se prive de este consuelo a los padres del niño muerto antes del bautismo, evitando confusiones doctrinales sobre la necesidad del bautismo.

-Queda a juicio del Ordinario del lugar el permitir las exequias por los bautizados no-católicos, «con tal de que no conste la voluntad contraria de éstos y no pueda hacerlas su ministro propio» (c. $1183 \S 3$ ). Estas condiciones mínimas, exigidas como algo básico, pueden ser complementadas por el Ordinario local atendiendo las circunstancias del lugar.

-En casos dudosos sobre denegación de exequias, «hay que consultar al Ordinario del lugar y atenerse a sus disposiciones» (c. $1184 \S 2$ ).

La doctrina se inclina generalmente por una interpretación estricta de esta denegación que, en definitiva, sólo se justificaría por el escándalo subsiguiente. Con J.M. ${ }^{a}$ Díaz Moreno y otros comentaristas, opinamos que la razón de la denegación deja de subsistir si: $10^{\circ}$ dan señales de arrepentimiento antes de morir, entendiendo éstas en sentido amplio; $2 .^{\circ}$ si se sabe, de cualquier modo, explicar al pueblo de Dios el sentido de las exequias en estos casos. En la práctica se admite una interprẹtación amplia en esta materia, consultando al Ordinario del lugar, si se puede.

c) Culto a los santos, imágenes y reliquias

- Se exige licencia escrita del Ordinario para reparar imágenes, preciosas por su antigüedad, valor artístico o por el culto (c. 1189).

El canon se refiere según J.M. ${ }^{a}$ Díaz Moreno a la licencia que se da en casos singulares y concretos; pero el Ordinario puede dar una normativa complementaria, que encuadre estos ćasos singulares, urgiendo no sólo que se pida la licencia cuando surja la necesidad, sino determinando cuándo hay obligación de poner en conocimiento de la curia los deterioros posibles de estas imágenes, para que la restauración sea posible.

\section{C) Lugares y tiempos sagrados}

La dedicación de un lugar sagrado corresponde al obispo diocesano y a quienes se le equiparan por Derecho, pudiendo delegar en cualquier obispo y en casos excepcionales a un presbítero.

a) La bendición de iglesias se reserva al obispo diocesano. Los demás lugares sagrados pueden ser bendecidos por el Ordinario. Ambos pueden dele- 
gar (c. 1207). Es rara una normativa diocesana sobre delegaciones en esta materia. Conviene observar su posibilidad.

-El Ordinario del lugar puede permitir el uso de un lugar sagrado para usos profanos, «siempre que no sean contrarios a la santidad del lugar» (c. 1210). No sólo es posible, sino también conveniente una legislación diocesana, que establezca unas normas especiales, a las que los responsables de los lugares sagrados, puedan atenerse. Se entiende que esta permisión recae sobre actos excepcionales, ya que si fuesen destinados habitualmente a estos usos, serían de aplicación los cc. 1212 y 1222.

b) Juicio del Ordinario del lugar sobre violación de un lugar sagrado (c. 1211) con ocasión de actos gravemente injuriosos. Al cambiar los criterios señalados en el Código de 1917 (c. 1172 § 1) por un criterio más bien subjetivo sobre la gravedad de los actos, que constituyen violación, el Ordinario del lugar puede establecer, en previsión, o como corrección, las normas pertinentes en las que se expresen, de algún modo concreto los criterios estimativos de la gravedad.

-Aunque se mantiene el concepto de violación, se modifica su naturaleza, dejando de ser una especie de mancha física con efecto automático. Ahora interviene el juicio del Ordinario local para valorar el hecho.

c) Prohibición de realizar ciertas celebraciones en oratorios (c. 1225).

-El Ordinario del lugar puede establecer las disposiciones convenientes, que crea pertinentes mediante decreto, al que deberán atenerse los inmediatos responsables de estos oratorios.

- Se requiere el permiso del Ordinario del lugar para establecer una capilla privada y celebrar en ella misa y otras funciones sagradas (cc. 1226 y 1228). La capilla privada se caracteriza por el destino a una familia, persona o personas físicas.

La multiplicación de estas capillas puede exigir disposiciones diocesanas para evitar abusos. Lo mismo puede suceder de acuerdo con el c. 1230 para la designación de un santuario, que exige la intervención del Ordinario local y a él compete la aprobación de sus Estatutos, aunque el santuario dependa de un Instituto religioso o Sociedad de vida apostólica (c. 1232).

\section{d) Intervención del Ordinario local en cementerios y panteones}

-Se requiere el juicio del Ordinario del lugar para bendecir cementerios y panteones pertenecientes a familias o personas jurídicas, distintas de las parroquiales e Institutos religiosos, que pueden tener cementerio propio (c. 1241 $-\S \S 1-2)$.

Esta disposición puede integrarse en los Estatutos diocesanos por los que se rijan los cementerios parroquiales o de la diócesis. 
- Hay un Derecho particular diocesano sobre el funcionamiento de los cementerios eclesiásticos (c. 1243). Se deberá tener en cuenta la legislación civil pertinente. Cada día es mayor el control del Estado.

e) Determinación de días especiales de fiesta o penitencia en la diócesis por los obispos diocesanos, sólo a modo de acto (c. 1244). Se limita esta designación per modum actus, no de forma estable o indefinida.

-El obispo diocesano puede dispensar en todo o en parte, de la observancia de los días de fiesta (c. 87) teniendo facultades complementarias los párro$\cos$ (c. 1245) con causa justa y según prescripciones del obispo diocesano. La legislación diocesana puede establecer de modo general el acomodo de esas prescripciones a las circunstancias locales, que los párrocos deberán seguir para otorgar las dispensas de que se trata.

f) Suplencia de la celebración Eucarística por Liturgia de la Palabra en días de precepto, como el día anterior por la tarde, conforme a lo que determine el obispo diocesano (c. $1248 \S 2$ ).

Conviene observar que si se verifica el supuesto de «carencia de la Eucaristía o misa por falta de sacerdote u otra causa grave», la asistencia a la Liturgia de la Palabra sólo está "vivamente recomendada», no preceptuada. Cómo se cumple con el precepto de participar de la misa (c. $1248 \S 1$ ). En relación con esto ver cc. $230 \S 3$ y 910 .

\section{D) Panorámica del derecho particular diocesano}

En la segunda parte de la ponencia de J.M. ${ }^{a}$ Díaz Moreno se expuso la panorámica del Derecho particular diocesano en España. Aunque no pude asistir a su exposición, tuve la oportunidad de llegar al diálogo. Se reconoció que, dado el poco tiempo de vigencia del Código de 1983, son escasas las normas diocesanas sobre los sacramentos en general y la ordenación de la Liturgia en relación con los cc. 834-848. Hoy por hoy son prácticamente nulas; pero es obvio que estas disposiciones aumentarán en el futuro y revestirán por fuerza un carácter orientador y pastoral, además de doctrinal.

En los Boletines y directorios o documentos de las distintas diócesis hay normas disciplinares interesantes sobre la catequesis, los aranceles, la procesión del Corpus, las exequias y los días festivos. Cada uno debe atenerse a lo que vaya saliendo en el Boletín de su diócesis y en el de la Conferencia Episcopal.

El coloquio estuvo muy animado, especialmente en torno a la confirmación, donde el ponente reconoció las razones de algunos objetantes sobre la edad y praxis de la Iglesia oriental. El corazón y la experiencia aconsejaban a mantener la primera comunión para los niños con uso de razón suficiente y la debida preparación, dejando la confirmación, como lo ha hecho la Conferen- 
cia Episcopal Española, para una edad mayor, en la pubertad, en torno a los 14 años, aunque se pueda administrar también en la edad de la discreción según el c. 891 , a no ser que exista peligro de muerte o haya una causa grave que aconseje otra cosa.

VIII. SITUACIÓN ACTUAL DE LAS RELACIONES ENTRE LA IGLESIA Y EL ESTADO

El día 13 de abril, a las 12 de la mañana, tal como estaba programado, Mons. Fernando Sebastián Aguilar, obispo Secretario General de la Conferencia Episcopal Española, clausuró las VI Jornadas Informativas con una disertación magistral y verdaderamente informativa sobre «la situación actual de las relaciones entre la Iglesia y el Estado», que ya eran tensas a la entrada de los socialistas en el gobierno y se han puesto aún más difíciles.

La Comisión mixta, con sus asesores, va trabajando y busca solución a los problemas pendientes de los Acuerdos de 1979. Interviene también la Nunciatura en representación de la Santa Sede. Se dieron los nombres de los que intervenían por parte de la Conferencia Episcopal: Mons. José Delicado Baeza, como Vicepresidente de la Conferencia; Mons. Elías Yañes, como Delegado de Enseñanza y Mons. Fernando Sebastián, como Secretario de la Conferencia. Por parte del Gobierno intervienen el Vicepresidente, el Ministro de Justicia y el de Educación.

Se informó sobre los logros alcanzados, los asuntos que están en trámite y los que aún están pendientes de cara al futuro. Hay problemas, cuya solución depende también de los gobiernos regionales o autonómicos. Está en trámite, por ejemplo, el reconocimiento de los títulos eclesiásticos; algo que debió de haberse hecho en otros tiempos.

Hay que reconocer que el pueblo español no estaba preparado culturalmente para la modernidad y que la fe, lo mismo que la Iglesia católica, tienen que buscar su propio lugar para aportar algo y dialogar. Las orientaciones del Concilio Vaticano II y del Código de 1983 pueden servir de cauces con espíritu de apertura y de comprensión. Lamentablemente, como ya había observado en una conferencia pronunciada en Club Siglo XXI, el 5 de diciembre de 1983, sobre «Vida religiosa y moral en la sociedad democrática española», se dan agresiones anticlericales y laicistas con la tentación, por parte de algunos, de dirigir a la Iglesia desde la política. Mientras la Iglesia no sea autónoma económicamente, no tendrá verdadera autonomía ni libertad operativa.

La aportación específica de la Iglesia es:

1. ${ }^{\circ}$ Orientar y confirmar la conciencia de sus miembros ante los problemas del momento. 
$2 .^{\circ}$ Ofrecer a la consideración de los no católicos unos criterios morales dignos de ser ponderados con rigor y con respeto.

3. ${ }^{\circ}$ Contribuir a clarificar, defender y enriquecer lo que considera parte de nuestro patrimonio moral histórico más allá de los límites y las pretensiones de ninguna oscura confesionalidad, ni indebidas ingerencias ${ }^{80}$.

Se están dando pasos en el progreso de la paz y de la convivencia, con respeto mutuo, libertad y voluntad de entendimiento. A veces hay intereses creados y diferencias ideológicas sobre la libertad de enseñanza que no se comparten. Por ambas partes se exige el derecho al respeto, a la propia intimidad y a manifestar su opinión. Tanto la Iglesia católica, como otras confesiones e instituciones civiles, tienen que recorrer su propio camino hacia un entendimiento.

\section{FIN DE LAS JORNADAS Y VALORACIÓN}

Las palabras finales corrieron a cargo del Presidente, como lo habían sido las de apertura ${ }^{81}$. No todo fue para informar sobre cuestiones canónicas. Hubo además de ponencias y coloquios, encuentros fraternos y de ágape, como la comida de homenaje al Presidente de Honor, Mons. Narciso Tibau Durán y al Socio de Honor, D. Tomás García Barberena, el querido profesor y amigo de muchos de los asistentes. En su nombre habló D. Lamberto de Echeverría, ya que $\mathrm{D}$. Tomás ni siquiera pudo estar presente. Con la chispa y agudeza que le caracterizan a D. Lamberto, retransmitió el mensaje de D. Tomás, haciéndolo un poco suyo, como todo lo que dice o trata este benemérito profesor salmantino de las dos Universidades. Vasco, como Unamuno, se ha afincado y realizado en Salamanca, donde sigue en la brecha, con gran capacidad de trabajo.

Tanto Mons. Narciso Tibau, como D. Tomás G. Barberena, son como dos modelos y patriarcas de la ciencia canónica por su vida sacerdotal, su perfil humano y su trabajo en la Asociación Española de Canonistas.

Con motivo de las VI Jornadas Informativas, según se había anunciado en la convocatoria, la Asociación celebró el día 12, a las 8,15 de la tarde, Asamblea general para renovar la mitad de la Junta Directiva. Se agradeció la colaboración de los cesantes y se felicitó a los nuevos miembros de la Junta Directiva.

80. F. SEBASTIÁN, Vida religiosa y moral en la sociedad democrática española (Madrid, EDICE, 1984) 19-26.

81. L. Martínez Sistach, Comunicación enviada a los miembros de la Asociación Española de Canonistas el 29 de abril de 1985 con un informe sobre el «Homenaje a Mons. Narciso Tibau y al Prof. D. Tomás G. Barberena». 
La valoración hecha por parte de los ponentes sobre el Derecho particular de la Iglesia española fue positiva. Los ciento y pico asistentes, en algunas reuniones más de 125 , quedaron satisfechos, unos porque se ponían al día y otros porque contrastaban sus opiniones, llegándose a veces a cierta pugna dialéctica con agudeza y caballerosidad en busca de soluciones correctas.

Dentro del Derecho universal (Código de 1983) y particular (diocesano) se debe reorganizar la vida parroquial, que es la mejor institución pastoral de la Iglesia, con su entorno socio-cultural, catequético, cultural, litúrgico, etc. Se requiere una pastoral de conjunto en el arciprestazgo con clérigos, religiosos y laicos comprometidos para satisfacer la demanda sacramental con una dimensión comunitaria y evangelizadora. $\mathrm{El}$ consejo pastoral puede ser una nueva pieza clave para coordinar los planes de evangelización, dentro de la religiosidad popular, con su inculturación, bajo la acción del Espíritu Santo.

F. CAMPO DEL POZO 